



\title{
RENDIDOS ANTE LA GUARIA MORADA
}

\author{
Sergio Orozco Abarca
}

Revista Herencia 33 (1), 2020 
306.05

R454r Revista herencia. - Año 1, N. 1 (1988)-.-

(San José, C. R.): Programa de Rescate y Revitalización del Patrimonio Cultural, 1988-v,

Semestral.

1. Costa Rica - Civilización - Publicaciones periódicas. 2. Folclore

- Costa Rica - Publicaciones periódicas.

ISSN 1659-0066

\section{CCC/BUCR}

$\bigcirc$

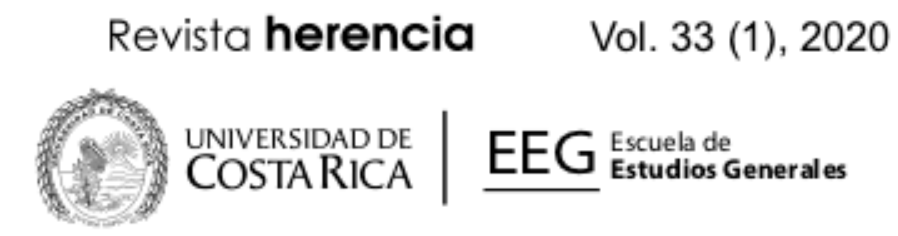

Herencia Semestral

ISSN 1659-0066

La revista Herencia es una publicación semestral de la Escuela de Estudios Generales de la Universidad de Costa Rica. Su propósito es la difusión de artículos sobre el rescate y la revitalización del patrimonio cultural.

\section{Consejo Editorial}

Dra. Macarena Barahona Riera, Excuela de Estudios Generales, Unversidad de Costa Pica, Costa Pica Dra. Susan Campos Fonseca, Sode del Alláricico, Escuela de Artes Musicales.

Universidad de Costa Auca, Costa Pica

Lic. Mel Vun Campos Ocampo, Escuela de Estudos Generales, ICOMOS de Costa Rica, Costa Rica D. Maricio M.rilo Herrera, Escuala de Avtropologla, Universidad de Costa Rica, Costa Pica

Mra. Jarol Nunez Moysa, Escuela de Estudos Generales, Unversidad de Costa Rica, Costa Rica

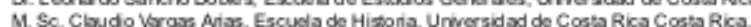

\section{Director-Editor}

Maq. Jairol Núnez Mope

Asistente y Soporte Web

Br. Jonathan Obando Artiaga

\section{Consejo Asesor Externo}

Dr. Jarge Baros, Ecole Lacarieme de Psychanalyse, Avgertina

Excmo. ismael Ferndindez de la Cuesta, Acadomia de Bellas Avtes Son Femanda, Expara avq. Andres Fernindez, Espocia ista en Patimonia, Costa Rica

Dr. Aurcio Horta, Urwersidad Naciona, Colombla

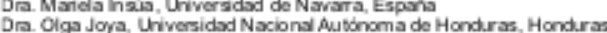
Ua Mried Reinoso, Grupo Edtorial Dostienpos. Mbxico

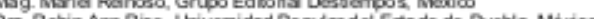
Dr. Luis Thenon, Unversidad de Laval, Consde

Dra. Marla Femanda Ugaide, Ponticia Universidad Casolica del Ecusdor, Ecuador Mag. Marlene Viaquez, Centro de Estudios Martianos, Cuba

Dra. Martina Vinatea, Unversidad del Pacifico. Perú

Mr. Martina Vinatos, Unversidad dar Pactica, Perú Dra. Magda Zarala. Unversidad Nacional Costa Rica

Disen̂o, diagramación y edición

Mag. Jairol Núnez Mory

Corrección de estito Con Jarol Nintez More

Escuela de Estudios Generales.

Universidad de Costa Rica.San Pedro de Montes de Oca, San José, Costa Rica.

Correo electrónico: herencia.eeg@ucr.ac.cr / Teléfono: (506) 2511-6342

http://revista s.ucr.ac.cr/index.php/herencia

Las opiniones expresadas en los artículos son responsabilidad exclusiva de los autores y las autoras y no reflejan necesariamente la posición de la Revista.

Imagen de portada: Guarianthe skinneri "Danae", propiedad de American Orchid Society (1975).

Cortesia del Dr. Daniel Pizarro Torres. 
"A esa familia nuestra, precolombina e indígena pertenece esta flor que ha sido electa como Reina y Señora de Costa Rica. La Guaria, princesa de las orquídeas americanas. La guaria no es extraña a nuestras leyendas y tradiciones. No es flor extranjera en la selva de América. Es una flor hermana de toda esa fresca montaña. Por eso no crece a ras de tierra, sino levantada en triunfo sobre la horqueta de sus árboles fraternales y amigos. Es la reina de las orquídeas. Por eso no está en los jardines, tímida y nerviosa, sino que prende agresiva en los pretiles de piedra áspera y dura. Si los guachipelines sustentan las casas de los abuelos, las guarias coronan con el airón de sus flores que crecen sobre las tejas de barro cocido. Es morada, por ser morena, como nuestra raza. Es morada porque ese es color de todos los gustos y de todas las horas. Con racimos de guarias pueden desposarse las novias y enterrarse los muertos. Con manojos de guarias se decoran los salones de baile y las naves del templo. Luce bien sobre las blusas de las colegialas y luce bien sobre las canas de las abuelas. Es el color suave y discreto que está en el linde donde se dividen las risas y las lágrimas. Es el último de los siete colores del espectro solar, es el límite intangible del iris, el primero que se esfuma en el disco de Newton. Es el color de los felices y de los atormentados. La Guaria Morada es también la Flor Nacional de Costa Rica, porque es la mística flor de la fe que heredamos de los mayores. Es la flor predilecta de la Cuaresma, la flor heráldica de la Santa Semana, que llama a los hombres al renunciamiento de sus vanidades y a pensar en Dios. Florece la Guaria con la lunación de marzo, que trae la más brillante de las lunas. La Guaria es fuerte y es humana. Su raíz se aferra a lo que es suyo: a los troncos de la selva americana, a las tejas de sus casonas abolengas, a los arcos de sus puentes, a las tapias que dividen los solares, a los pretiles que separan los predios, a las torres que coronan sus templos. Fuertes y rudas son sus hojas, como las manos callosas de los campesinos; suaves y frescos son sus pétalos, como los labios de las campesinas. Es la flor de los pobres y la flor de los ricos: es la flor de todos los costarricenses. ... Por nuestra la queremos. Por nuestra la defendemos. Por nuestra la ponemos sobre las cruces de nuestros muertos, sobre el regazo de nuestras madres, sobre la frente de nuestras novias...".

Luis Dobles Segreda (La Guaria Morada), en Paris Soir, octubre 1939 y en Revista del Instituto de Defensa del Café de Costa Rica, junio 1945. 

Revista Herencia, Vol. 33 (1), enero-junio, 2020.

\title{
RENDIDOS ANTE LA GUARIA MORADA
}

\author{
Surrended before the guaria morada
}

\author{
Sergio Orozco Abarca \\ Universidad de Costa Rica, Costa Rica \\ sergiorozco@gmail.com
}

Recibido: $14-10-2019$

Aprobado: 29-11-2019

\begin{abstract}
Sergio Orozco Abarca es graduado en Filología Española, de la Universidad de Costa Rica. Ensayista e investigador de temas culturales. Varios de sus artículos se han publicado en periódicos nacionales y en revistas especializadas del exterior. Premio 18 de Abril (ICOMOS, Costa Rica), año 2018.
\end{abstract}

Rica; símbolo nacional

\section{RESUMEN}

El presente artículo comprende un estudio sobre la guaria morada, símbolo nacional de Costa Rica. Para ello se realiza un acercamiento histórico a las orquídeas, desde el momento de su bautizo hacia el siglo IV A.C., hasta que surge la fiebre por ellas en Europa en el siglo XVIII, seguida por el hallazgo de la guaria morada en las selvas de Guatemala, y culminando con la presencia de la planta en Costa Rica. También se hace un recorrido sobre su nombre, y se rescatan unas fascinantes crónicas de guarias. Ello con el fin de honrar este ícono que resguarda en la memoria como parte constitutivadel ser costarricense.

Palabras clave: guaria; guaria morada; Guarianthe skinneri; Costa

\begin{abstract}
This article elaborates a study about the "guaria morada", the national symbol of Costa Rica. To do this, it makes a historical approach to orchids, which begins in the fourth century BC, approximately, when the species was baptized, continues with the analysis of the eighteenth century period in which they become a trend in the European market, followed by the moment of his discovery of the "guaria morada" in the jungles of Guatemala, and culminates with the discovery of the plant in Costa Rica. Besides, an analysis of the name "guaria morada" is outlined, and a series of fascinating chronicles regarding different guards are presented. To honor this icon that safeguards in memory as a constituent part of being Costa Rican.
\end{abstract}

Keywords: guaria; guaria morada; Guarianthe skinneri; Costa Rica; national symbol 


\section{Introducción}

Cuando usted escucha hablar de "la guaria morada", ¿piensa primero en la canción o en la flor? ¿O en ambas a la vez, admitiendo que son inseparables, como las caras de una moneda, y que los acordes ticos de la canción y el resplandor púrpura de la flor son cuerpo y alma? ¿Carreta y buey? ¿Trueno y relámpago? ¿Barca y mar?

Una brevísima imagen de Mario Sancho (Memorias, 1961) ${ }^{1}$ evocando el Cartago de su niñez, ilumina nuestros sentidos con una fuerte señal reminiscente. La descripción de don Mario, rápida como un meteoro, deja en nosotros su estela inolvidable.

Cartago, a inicios del siglo $\mathrm{XX}$, era como una ciudad de entreguerras, donde aún se recordaba la diáspora de los padres jesuitas y el incienso del viático de doña Gertrudis Peralta; pero donde, sobre todo, perduraba el terror de los abuelos por el terremoto del 41, y nadie avizoraba el que estaba a las puertas. Allí, los asombrados ojos de Mario Sancho, niñito, contemplaban en Semana Santa, el espectáculo inigualable de los techos de teja sobre los cuales, un sinnúmero de guarias, agitadas por el viento, el agua y la perenne bruma, convertían la ciudad en un enorme altar ceremonial, listo para recibir al Nazareno.

Narrada al vuelo por la pluma maestra de don Mario, esa imagen idílica fue el verdadero punto de partida de este artículo. Jamás pensé que una visión de tan profunda raigambre tica, como un cuadro de Fausto Pacheco, en el fondo constituyera una tragedia, porque el deleite de los abuelos por las guarias y luego su desmesurado trasiego, casi han devastado una especie sin igual.

La preciosa e inocente guaria sobre la tapia entejada (representación idealizada de la idiosincrasia costarricense), vino a ser el preludio de su exterminio, porque la violación sistemática de su ecosistema natural, la condenó prácticamente a la extinción. Fue así como los techos, las tapias y los altares de los santos consumieron la vida de una especie única, que hoy solo sobrevive en la ciudad, al cuidado irregular del hombre, y no al amparo de la naturaleza, tal como fue creada.

\footnotetext{
${ }^{1}$ Mario Sancho Jiménez, escritor, educador, diplomático y político costarricense, nació en Cartago en el año 1889, y falleció en 1948. Sus Memorias fueron escritas antes de su muerte, pero no se publicaron hasta el año 1961.
} 
Por fortuna y sobre todo gracias a la denodada labor de científicos, asociaciones y cultivadores, todos ellos inspirados en los pioneros de las orquídeas (Lindley, Bateman, Skinner), las guarias moradas tendrán futuro, aunque, admitámoslo, ya no en su estado nativo.

Seducido por su historial de maravillas, muy rápidamente caí en cuenta que no podía, de ninguna forma, referirme a la singular flor sin hablar de la canción, que viene siendo, como nuestro segundo himno nacional. Sin embargo, también comprendí que incluir en un mismo artículo "flor" y "canción", podría no ser oportuno, pues quizás me obligaría a recortar excesivamente el texto, a lo que siempre rehúyo. De manera que, al final, decidí escribir dos artículos. El primero es este, que contiene un acercamiento histórico a las orquídeas, desde el momento de su bautizo hacia el siglo IV A.C., hasta que surge la fiebre por ellas en Europa en el siglo XVIII, seguida por el hallazgo de la guaria morada en las selvas de Guatemala, y culminando con la presencia de la planta en Costa Rica: el porqué de su nombre, y unas fascinantes crónicas de guarias.

El segundo artículo, cuya investigación y producción resultó tan interesante como el primero, explicará, los hechos que cimentaron la canción "La guaria morada", y nuestro intento de poner en claro, a partir de fuentes primarias, quién o quiénes fueron sus autores.

En el proceso investigativo conocí a personas amantes y expertas, tanto de la planta como de la canción. Fueron claves los invaluables aportes del Ing. Jaime García González, catedrático universitario, quien ha dedicado varios años de su vida reuniendo datos acerca de la guaria morada, en sus múltiples facetas. Todos sus hallazgos formarán parte de un libro que, a no dudar, será un hito literario e investigativo alrededor de este maravilloso símbolo nacional. Igualmente, me resultaron de mucho provecho los consejos y documentos facilitados por el Arq. Carlos Ossenbach Sauter, destacado investigador de las orquídeas, con publicaciones relevantes, dentro y fuera de nuestro país. Quiero también distinguir la gentileza del Dr. Daniel Pizarro Torres, reconocido cultivador de orquídeas, quien me contó la asombrosa historia de la guaria morada de doña Danae de Brenes.

Amada por ricos, pobres, blancos, negros, nativos, letrados e iletrados, la guaria morada es, ante todo, una figura literaria: una flor de orgullosa humildad. Ella acompaña a Costa Rica desde siempre, y es tan tica que parece un grave olvido 
no haberla incluido en nuestro escudo nacional. ¡Si ahí cabía, entre los volcanes! Aunque amenazada por la extinción es también una flor joven, que apenas cumplió 180 años de ser conocida por la ciencia moderna, y solo 80 años de ser nuestra flor nacional.

He de confesar que hubiera seguido por el equivocado camino de indiferencia a las guarias, de no ser por la cautivadora imagen narrada por don Mario Sancho y, desde luego, por la canción campesina, que nos arrebata con su hipnótica tertulia de guitarra y marimba; pero por sobre todo gracias a sus fantásticas metáforas, deslumbrantes, pródigas y honradas como taller de orfebre. Fue, en suma, gracias a los múltiples encantos de "flor" y "canción" como caímos rendidos ante la guaria morada.

\section{Las orquídeas: su origen}

Teofrasto de Ereso, discípulo de Aristóteles, contempló los tubérculos ovalados de aquella planta mediterránea, con hojas carnosas y flores exuberantes, y exclamó: "Orjis!"2. Fue así como bautizó el género de estas plantas. Con el tiempo, el nombre "Orjis" u "Orchis" se aplicó a todas las plantas similares, y así surgió el nombre de la familia de las orquídeas u orquidáceas. Sin embargo, su historia inicia hace unos 100 o 200 millones de años en el archipiélago de Borneo, de donde se extendieron a todos los continentes (Rivera, 1998, p. 23).

Las primeras evidencias del interés humano por las orquídeas surgieron en China, hace unos 3000 años. Confucio, impregnado de sabiduría, dijo que "relacionarse con buenas personas se asemeja a entrar en una habitación llena de Lan". Lan quiere decir "orquídea fragante" en chino (Rigby, 2005, p. 3). Durante la Edad Media, tubérculos de orchis fueron usados para elaborar afrodisíacos y pociones mágicas.

En varias culturas indígenas de América se conoce su uso extendido, como planta medicinal y ceremonial, tanto para ofrenda a los dioses como a los muertos (Coutiño-Cortés, 2018). La primera referencia de las orquídeas en el Nuevo Mundo data del año 1552, cuando Hernán Cortés, en una carta al rey Carlos V, menciona el maravilloso aroma de una sustancia extraída de las cápsulas de la Vainilla spp.

\footnotetext{
${ }^{2}$ Orjis, es testículo en griego.
} 
La familia de las orquídeas comprende aproximadamente 25000 especies y más de 60000 híbridos y variedades, producidos por científicos y floricultores, mediante clonación, hibridación, etc. Esta familia es el grupo más diverso y extenso de plantas con flor sobre el planeta (Alvarado, 2000, p.1). Se encuentran en casi todas las regiones, excepto en zonas de clima desértico o polar, y su mayor abundancia procede de la zona intertropical. Las orquídeas son plantas herbáceas ${ }^{3}$, pueden ser terrestres o epífitas (en su mayoría) ${ }^{4}$, y ocasionalmente trepadoras. La flor está formada por tres piezas externas denominadas sépalos (dos laterales y uno dorsal) y tres elementos internos (pétalos), una de ellos modificada en un labio o labelo, de mayor tamaño y color más intenso que los otros $^{5}$.

\section{Orquideomanía}

Entre el año 1634 y 1685 floreció, en Holanda, la primera orquídea tropical llevada a Europa, la Brasavola nodosa, proveniente de Curazao (Rivera, 1998, p. 25). En el año 1731, la especie Bletia verecunda, fue la primera orquídea tropical en florecer en el Reino Unido. Perteneció a la colección de sir Charles Wager, pero originalmente formaba parte de la colección del "Chelsea Physic Garden" (Rigby, 2005). Estos hechos encendieron la fiebre de las orquídeas, pero a la vez engendraron una enorme tragedia: el saqueo indiscriminado de ellas en las colonias europeas de América, Asia y África. Fue así como de la noche a la mañana, las orquídeas, que crecían libremente en los bosques, fueron arrancadas de los árboles, de las piedras y del suelo, pues "representaban la fascinación y belleza de países lejanos" (Ossenbach, 2004). Las expediciones para ir a la búsqueda de las orquídeas duraban meses, en tierra y mar, y no siempre las plantas eran bien empacadas o recibían el trato correcto, por lo que pocas llegaban vivas a su destino. Pese a ello, se pagaban cifras astronómicas por algunas especies, y hubo personas que se enriquecieron con su trasiego.

A comienzos del siglo XIX, aunque persistía la explotación de tierras en busca de orquídeas, los botánicos iniciaron la publicación de experiencias exitosas en su cultivo. John Lindley, considerado el padre de las orquideología, publicó varios informes y libros con su clasificación, estableciendo las bases para el cultivo de estas plantas y la producción de híbridos (Rivera, 1998, p. 25).

\footnotetext{
${ }^{3}$ Plantas similares a las hierbas, con tallos tiernos, que no producen órganos duros o leñosos.

${ }^{4}$ Epífita o epifita se refiere a cualquier planta que crece sobre otro vegetal u objeto usándolo solamente como sustrato, sin alimentarse de él. Si lo hiciera, sería planta parásita.

${ }^{5}$ Ver https://es.wikipedia.org/wiki/Morfolog\%C3\%ADa floral
} 
James Bateman (1811-1897) fue un pionero en el cultivo de orquídeas y la aplicación de la ciencia en su reproducción. Sostenía correspondencia frecuente con el naturalista Charles Darwin, y está documentado que en el año 1862, le hizo llegar una caja con orquídeas, porque Darwin se encontraba fascinado en el estudio de estas inéditas plantas ${ }^{6}$. Pero el legado de Bateman y por el cual es reconocido en la historia de la orquideología es extraordinario. En 1837 - ¡a los 26 años!- empezó a publicar, por partes, un libro desmesurado en peso y escala ( 72 × $53 \mathrm{cms}$ y casi 20 kilos de peso), que forma parte esencial, aun hoy, del estudio de estas fabulosas plantas. El libro se llamó The Orchidaceae of Mexico and Guatemala (Orquídeas de México y Guatemala). Solo se imprimieron 125 copias de la primera edición, pues no iba dirigido al público general, y está considerado como el libro más grande y más caro de orquídeas jamás producido (Ossenbach, 2004). Era tan grande y por lo tanto difícil su consulta y lectura que se debieron construir mesas o atriles especiales. Para darnos una idea de su valor actual, en el año 2013, la casa Christie's de Londres, subastó un ejemplar, que acabó vendiéndose en 75000 dólares (unos 45 millones de colones de 2019). El comentario de la subasta indicaba que es: "probablemente el libro botánico más fino, y ciertamente el más grande jamás producido con placas litográficas. En tamaño y esplendor, el gigantesco folio de Bateman eclipsa las obras de todos los anteriores y posteriores a él"8.

Lo grandioso de dicho libro, para el propósito de este artículo, es que fue en una de las 40 placas litográficas que lo ilustran, donde se menciona por primera vez la Cattleya skinneri (hoy Guarianthe skinneri), nuestra guaria morada. En esa época, apenas iniciaba la fotografía, así que para muchas personas, aquella colección de imágenes exóticas era como mirar flores de otro planeta. Más adelante y por fortuna, tendremos que volver, obligatoriamente, al legendario libro de Bateman.

\footnotetext{
${ }^{6}$ En carta de Bateman a Charles Darwin (1 de febrero de 1862) se demuestra la alegría de Darwin al recibir un envío de orquídeas por parte de Bateman. Disponible en Darwin Correspondence Project de la Universidad de Cambridge. http://www.darwinproject.ac.uk/letter/?docld=letters/DCP-LETT3356.xml;query=3356; brand=default; hit.rank=1\#hit.rank1

7 Existe una copia digitalizada, completa y de muy buena calidad del libro de Bateman en la "Biodiversity Heritage Library": https://www.biodiversitylibrary.org/item/15471\#page/48/mode/1up

$8 \quad$ Ver: $\quad$ https://www.christies.com/lotfinder/Lot/bateman-james-1811-1897-the-orchidaceae-of-mexico5698056-details.aspx
} 
Figura 1. Estas imágenes corresponden a la restauración de un ejemplar del libro de Bateman realizada por la biblioteca Peter H. Raven del Jardín Botánico de Missouri, en el año 2018. Gracias a ellas se puede apreciar las dimensiones del singular libro.

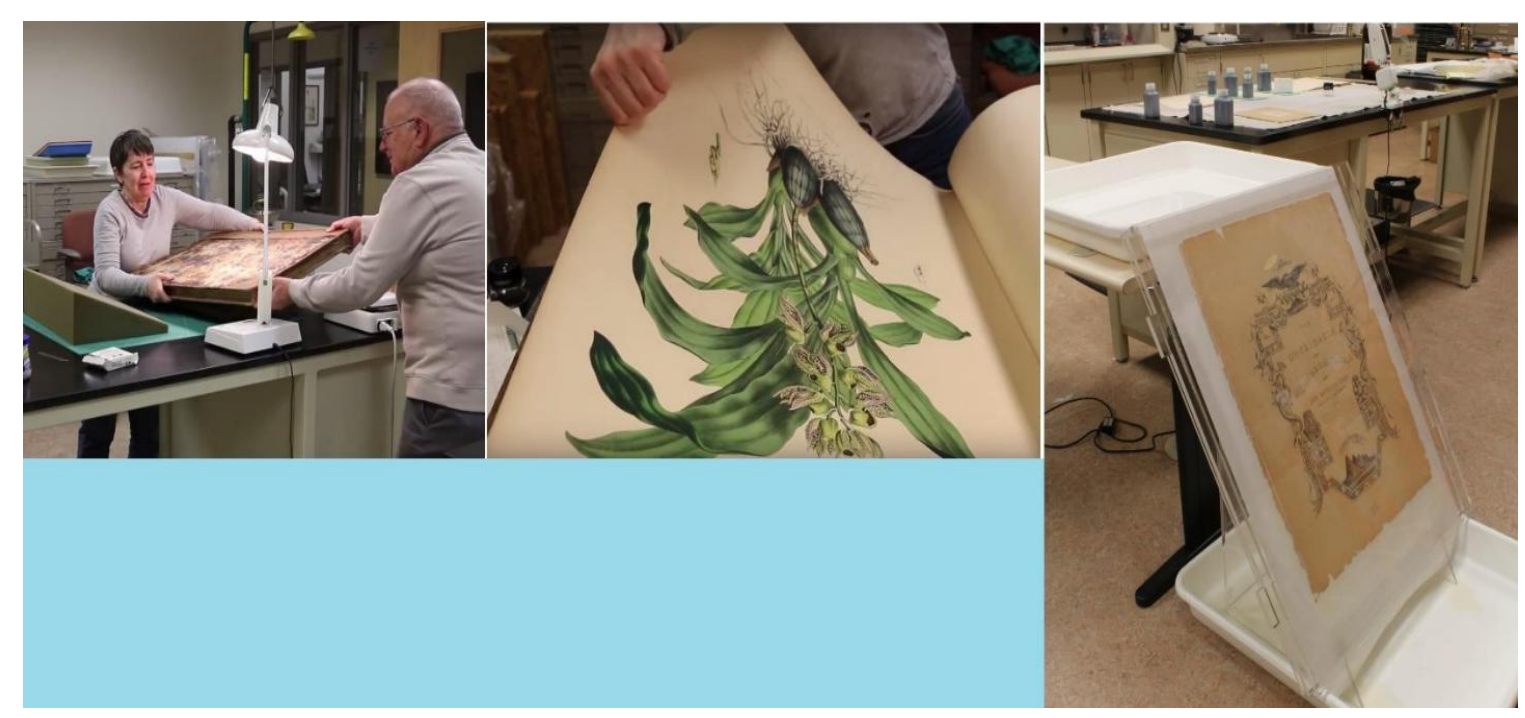

Composición: Sergio Orozco A. Información disponible en: https://discoverandshare.org/2018/02/17/from-the-library-rebuilding-the-bateman-book-part-1/.

En Chatsworth, Inglaterra también se escribe una página de esta historia. Chatsworth es una extensa propiedad ubicada en el condado de Derbyshires su construcción se inició en el año 1553 por William Cavendish, tesorero del rey Enrique VIII. La propiedad ha permanecido en manos de la misma familia hasta hoy. Su dueño actual es Peregrine Cavendish, $12^{\circ}$ Duque de Devonshire. La propiedad tiene una larga conexión histórica con el estudio de las orquídeas, pues fue el hogar de una de las colecciones privadas más extensas del Reino Unido, en toda la era victoriana. El $6^{\circ}$ Duque de Devonshire (William Cavendish), junto con su jardinero jefe, sir Joseph Paxton, fueron pioneros en la recolección de orquídeas, y se sabe que tenían asignados buscadores profesionales de estas plantas en varias regiones del mundo. 
Joseph Paxton es un personaje excitante. Gracias a su inmenso talento como paisajista y experto en invernaderos ${ }^{9}$, construyó en Chattsworth, entre 1836 y 1840, un gigantesco edificio de hierro y vidrio conocido como la "Gran Estufa" (Great Stove). Medía $69 \mathrm{~m}$ de largo, $37 \mathrm{~m}$ de ancho, y $20 \mathrm{~m}$ de altura. Era el edificio de vidrio laminado más grande del mundo, cuyo costo superaba las 30 000 libras esterlinas. Desde una galería aérea interna se divisaban las copas de enormes árboles tropicales, en cuyas ramas se posaban aves exóticas con sus dulces trinos y gorjeos. Una multitud de peces plateados nadaban en estanques llenos de nenúfares y lirios, entre una colección de orquídeas y otras plantas sin rival, que imprimían al ambiente un indescriptible aire de meditación y paz. Solo faltarían acá algunos árboles del Génesis, para alcanzar la imagen misma del Jardín del Edén.

A inicios del siglo XX, la orquideomanía tocó a su fin. La orquídea fue, no cabe duda, la flor del lujo victoriano; pero así como esta era decayó, su flor hermosa también se fue marchitando. El costo para mantener los invernaderos, en especial sus sistemas de calefacción, empezó a ser muy alto, principalmente por el faltante de carbón, agudizado por la primera Guerra Mundial. Tanto así que el espectacular invernadero de Chattsworth corrió la ingrata suerte de otros: sus plantas y árboles empezaron a morir, hasta que fue demolido en 1920.

\footnotetext{
${ }^{9}$ Fue una muy grata sorpresa que la figura de Joseph Paxton surgiera en relación con las orquídeas, pues conozco parte de su biografía gracias al estudio que realizo, desde hace varios años, de las fuentes victorianas. El gran invernadero o la Gran Estufa de Chatsworth fue la prueba de Paxton para emplear vidrio prefabricado y hierro estructural, en la que sería su obra maestra, el Crystal Palace, el inmenso edificio que acogió la Gran Exhibición de Londres, en 1851. Un año antes, la Comisión Real organizó un concurso para el diseño del gran pabellón de la Exhibición, al que se presentaron 254 diseños. Paxton bosquejó su proyecto, muy inspirado en Victoria Regia House (del Jardín Botánico de Kew), y fue el ganador absoluto, pese a no ser arquitecto. En dicha exhibición, la compañía Coalbrookdale de Shropshire, mostró, entre otros notables objetos, la fuente "Cupido y el Cisne" (conocida en Inglaterra, como Boy and Swan, diseño del escultor John Bell). Se sabe que la compañía fabricó al menos siete réplicas de esta fuente, una de las cuales está en nuestro país: la fuente "Cupido y el Cisne" (instalada para conmemorar la primera cañería de la ciudad de San José), que estuvo en el Parque Central, desde 1868 hasta 1944, y que hoy, después de 150 años, luce en la Universidad de Costa Rica. Para más información acerca de la historia de esta fuente, consulte el artículo "La Fuente de Cupido y el Cisne en la Universidad de Costa Rica"(https://revistas.ucr.ac.cr/index.php/herencia/article/view/35770/36497). Otra de las razones para recordar a sir Josep Paxton, aparte de las orquídeas y las fuentes, es que fundó un periódico (Daily News, 1846), y contrató como director, nada menos que a Charles Dickens; finalmente, cuando usted saboree un banano de la variedad "Cavendish" (esos hermosos y exquisitos bananos de Dole, Chiquita, etc.) tenga presente que fue Joseph Paxton el primero en cultivarlos en Europa, dentro de la Gran Estufa de Chattsworth, hacia el año 1835. Para más información acerca de Joseph Paxton se puede consultar este artículo (en inglés): https://www.oxforddnb.com/view/10.1093/ref:odnb/9780198614128.001.0001/odnb-9780198614128-e-21634
} 


\section{Las catleyas: preámbulo de la guaria morada}

En 1816, el naturalista inglés William Swainson viajó a las selvas del norte de Brasil en busca de helechos, musgos y plantas tropicales, para enviar a coleccionistas y jardines botánicos del Reino Unido. Uno de aquellos fardos de plantas recogidas en el estado de Pernambuco, en 1817, iba destinado al Jardín Botánico de Glasgow (Escocia); el Jardín, a su vez, a pedido de Swainson, envió una de las plantas a un experto horticultor, llamado William Cattley, que poseía un gigantesco invernadero en las afueras de Londres, donde cultivaba todo tipo de plantas, incluyendo exóticas orquídeas.

La historia de la Cattleya, género de orquídeas al cual pertenece nuestra guaria morada, contiene, en su origen, uno de los mitos más fascinantes de la botánica. El mito indica que Swainson envió a Cattley un paquete de helechos desde Brasil, y que para protegerlos, rellenó el fondo de la caja con despojos de plantas y raíces que tenía a la mano. Una vez desenvueltos los helechos, a Catttley le intrigó aquel material de empaque, y de él rescató una diminuta planta casi muerta, le dio cuido y con el tiempo, aquella dio una flor espectacular, que vino a ser la famosa Cattleya labiata; una variante del mito indica que los restos fueron tirados en un rincón, y que para sorpresa de Cattley, al tiempo, espontáneamente brotó de ellos la famosa Cattleya ${ }^{10}$. Con detalles más o menos similares, muchísimas fuentes citan esta romántica historia como el origen del género Cattleya.

Sin embargo, otras fuentes como el Jardín Botánico de Nueva York ${ }^{11}$, uno de los más grandes y respetados jardines botánicos del mundo, refuta esta historia e indica que Swainson ya había visto la planta en flor en las selvas de Brasil, y conocía muy bien el interés de Cattley en las orquídeas. Por tanto, empacó deliberadamente la planta, como parte de un envío mixto de plantas tropicales

\footnotetext{
10 Algunos autores atribuyen la invención el mito de la Cattleya labiata a Frederick Boyle, un escritor especializado en orquídeas. Viajó a áreas remotas de las selvas del mundo, donde vio crecer orquídeas silvestres, tanto en Asia como en América, y construyó un mundo de intriga, engaño, amor, caos y asesinatos alrededor de las orquídeas, que luego publicaba en sus libros. Su mayor legado fue un libro escrito en 1893 , titulado "About Orchids - A Chat", donde narra la forma en que la Cattleya llegó a Europa. Boyle cuenta que Swainson, envió a William Cattley, desde Brasil, un paquete de líquenes, cuyo material de embalaje (las plantas de labiata), fueron arrojadas bajo un banco y que para sorpresa de todos, el material floreció en pocos meses, con hermosas flores de orquídeas. En defensa de Boyle hay que decir, sin embargo, que en su texto, él mismo indica (¿curándose en salud?) que "... las leyendas y los mitos rodean ese gran evento". Más información en: https://chadwickorchids.com/content/myth-maker

${ }^{11}$ https://www.nybg.org/blogs/plant-talk/2013/01/gardens-and-collections/crazy-for-cattleyas/
} 
dirigidas al Jardín Botánico de Glasgow y, por medio de este, a Cattley. Curiosamente, la planta de Cattley floreció, en sus invernaderos, un año antes que las plantas de Glasgow.

W. Cattley tenía previsto publicar un libro Ilamado "Collectanea Botanica" (1821), una descripción y catalogación de su extenso surtido de plantas. Para hacer este trabajo, contrató nada menos que al afamado botánico John Lindley, como editor de su obra. Lindley analizó la planta y descubrió, gratamente sorprendido, que ella pertenecía a un género de orquídea desconocido para la ciencia, al que de inmediato bautizó como Cattleya, en honor a sir William Cattley, la primera persona en cultivarla con éxito en el Reino Unido (Ossenbach, 2004). De hecho, a la planta la llamó Cattleya labiata, debido al gran tamaño de su labelo.

\section{Skinner encontró la guaria morada en Guatemala}

Hemos hablado de Bateman y de su colosal libro de orquídeas. Si resultó fantástico su legado, igual o superior nos parecerán las proezas de George Ure Skinner (1804-1867). A él le debe la ciencia buena parte del conocimiento de muchas plantas de Centroamérica y, los costarricenses en particular, el hallazgo, difusión, y conocimiento acerca de la guaria morada, cuyo nombre científico, muy justamente, lleva su apellido. El propio Bateman, en honor de su admirado colector, llamó "Cattleya skinneri" a esta singular orquídea que, desde Guatemala, le envió Skinner, hacia el año 1839. Obviamente, no fue Skinner el primer ser humano en contemplar aquella maravillosa planta y su adorable flor; fueron, desde luego, los aborígenes de Mesoamérica. Sin embargo, a él le debemos la introducción de la guaria morada a la corriente científica mundial.

G. U. Skinner nació en Escocia. Fue hijo de un clérigo y nieto de un obispo de la iglesia episcopal escocesa. Aun con estos antecedentes, se rehusó a seguir la carrera eclesiástica, y vivió seducido por la diplomacia, el comercio, pero sobre todo, por el drama y la aventura.

Llegó a Guatemala en 1831 y se unió a Carl R. Klee, con quien fundó "Klee, Skinner \& Co", que llegó a ser la principal firma de comerciantes extranjeros en Guatemala. Se especializaban en exportar tintes naturales (índigo y carmín) e importar mosquetes, textiles y otros productos manufacturados. 
Ossenbach (2004), indica que Skinner se involucró activamente en la vida política, comercial y diplomática de la Federación Centroamericana, y gozó de la simpatía de la mayoría de los políticos centroamericanos de la época. Asimismo, desde su llegada a Guatemala, se dedicó a colectar aves e insectos que enviaba a Inglaterra, persuadido por su amigo, el ornitólogo y taxidermista John Gould.

Es una gran pena que no exista (o por lo menos no se conoce) un diario o libro escrito por Skinner, donde narre sus experiencias, aunque se sabe que muchas cartas entre él y Bateman se perdieron -por el contrario, se conservan cartas suyas con otros coleccionistas y científicos ${ }^{12}$. Peor aún: es una fatalidad que se ignore el sitio exacto donde Skinner encontró la Cattleya skinneri, sus impresiones al verla, la forma en que la envió a Bateman, y ulteriores diálogos entre ellos, acerca de la planta. Sin embargo, la profesora Carol Siegel indica que la C. skinneri fue encontrada en un sitio cercano al Golfo Dulce (Lago de Izabal), en Guatemala (Siegel, 2013).

En general, se cree que Skinner, durante sus treinta años de amistad con Bateman, introdujo aproximadamente 100 orquídeas nuevas para el cultivo y estudio (Siegel, 2013).

Skinner enviaba cajas con orquídeas a Inglaterra, pero muchas veces él mismo las llevaba haciendo un viaje destinado solo a los intrépidos, pues tenía que atravesar las montañas de Guatemala en mula, un viaje que duraba una semana, con buen tiempo; pero hasta un mes en los atroces inviernos del trópico. Una vez que alcanzaba el puerto de Izabal, Ilamada en su época la ciudad más caliente de la tierra (Siegel, 2013), debía tomar un bote hasta Belice (entonces Honduras Británica), antes de abordar el siguiente paquebote a Liverpool o Southampton, en un viaje que la mayoría de las veces demoraba dos meses. Aunque se sabe que Skinner completó el viaje de regreso entre Inglaterra y Guatemala, no menos de diecinueve veces (Milligan, 2003).

\footnotetext{
${ }^{12}$ En Ebay, sorprendentemente, está a la venta un archivo que contiene muchas cartas y documentos relativos a la vida de Skinner; quién sabe si en él se encuentre la referencia del primer envío a Inglaterra de la guaria morada! En la sección de fotos, encontrará una imagen de una parte de este archivo. https://www.ebay.com/itm/Orchids-Skinner-Guatemala-Scottish-Episcopal-Church-Important-Family-Archive$\underline{113425121594}$
} 
Skinner pasó una décima parte de sus treinta años de carrera en viajes intercontinentales templando los nervios contra ladrones, asesinos y naufragios; pero también sorteando el ímpetu de la naturaleza, en territorios colmados de abismos, tigres, serpientes y mosquitos.

Figura 2. George Ure Skinner. Imagen colección de RHS, Lindley Library

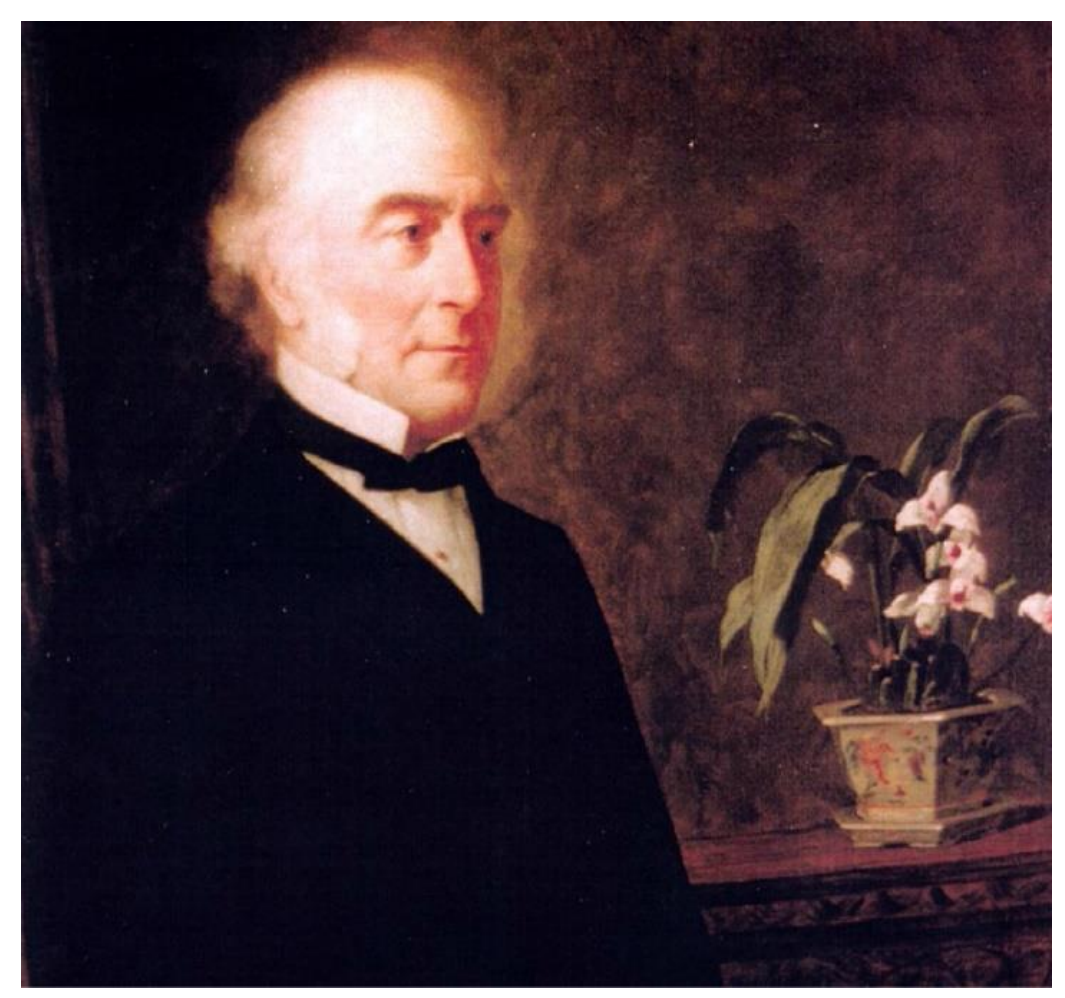

Fuente: imagen publicada en "Bateman, Skinner and the Kiddies" por Carol Siegel, 2013

Por fortuna, el propio Bateman, en el hermoso texto que acompaña a la Cattleya skinneri, en su famoso libro, nos ofrece detalles inapreciables de la vida de Skinner en Centroamérica. Dice Bateman (1837 / 1843) que la poca cantidad de europeos, y la ausencia casi total de residentes ingleses en Guatemala, hacían imposible obtener información precisa sobre la historia natural de ese país. Agrega, que tal estado de cosas pudo permanecer así por mucho tiempo, de no ser porque accidentalmente escuchó hablar de un caballero llamado Skinner, comerciante y dueño de extensas propiedades en Guatemala, quien hace poco había enviado un paquete de insectos al Museo de Historia Natural 
de Manchester. Este hecho, agrega Bateman, "trajo un tenue rayo de esperanza, porque la entomología y la botánica son ciencias afines", y como Skinner ya había hecho tanto por una de ellas, posiblemente le daría una mano a la otra." Fue así como Bateman decidió enviar una carta a Skinner, pidiendo su favor. Datada en el año 1834, la misiva fue escrita con cierta timidez y escepticismo, pero Skinner, que nunca había oído hablar de las orquídeas, quedó extasiado con la descripción y dibujos hechos por Bateman, y desde ese momento empezó a trabajar incesantemente, para sacar de sus escondites aquellos tesoros y trasladarlos a invernaderos del Reino Unido, donde serían reproducidos y estudiados con fruición.

En tal búsqueda, dice Bateman, no hubo sacrificio, peligro, ni dificultad que Skinner no enfrentara; ya fuera en la enfermedad o en la salud, nunca perdió oportunidad de añadir algo a la extensa lista de sus descubrimientos botánicos. En un viaje a Inglaterra en 1837, Skinner fue detenido en cuarentena, por más de quince días, en el Castillo de San Felipe de Lara, en el Golfo Dulce; a esta detención le debemos algunas plantas valiosas, y a su posterior naufragio en la costa del Pacífico, muchas más. Cuando fue arrojado, luego de perder su barco, a una playa inhóspita, su primera preocupación no fue asegurar alimento, sino saber si en el sitio había alguna planta interesante.

Seguidamente, en un proverbial párrafo que refrenda el homenaje a Skinner, Bateman incluye la primera descripción de la Cattleya skinneri (guaria morada) de la historia. Dice así:

"Por lo tanto, sin más prefacio, debemos pedirle a [Skinner] que acepte los únicos reconocimientos para otorgarle, en el poder de la ciencia que él tanto ha defendido. Desafortunadamente, existe ya un género peruano llamado Skinneria (pero no puesto en honor de nuestro amigo). Por lo tanto, no podemos hacer más que seleccionar algunas especies que no desacrediten su nombre, y nos confesamos incapaces de concebir uno mejor adaptado para nuestro propósito que la magnífica "Cattleya" representada en la lámina adjunta [lámina 13 del libro]. EI color de la "Cattleya skinneri" (que ya debemos llamarla así por su título) es el rosa más brillante e intenso, y hay una delicadeza en ella que no es superada por ninguna planta conocida. Es fácil de cultivar, y produce sus flores libremente en el mes de marzo; cuando se expanden por primera vez, son de un tono muy pálido, y no más de la mitad del tamaño al que alcanzan en el transcurso de un día o dos. La especie se distingue fácilmente de todas las Cattleyas hasta ahora conocidas, por la extrema brevedad de sus columnas, que no exceden la cuarta parte de la longitud del labelo. El Sr. Skinner encontró esta planta casi exclusivamente en las partes más cálidas de Guatemala y a lo largo de las costas del Pacífico". (el destacado es nuestro). 
Figura 3: La famosa "Lámina 13" del libro de Bateman, donde se muestra, por primera vez a la ciencia mundial, la Cattleya skinneri (guaria morada). Ilustración de Augusta Withers, litografiada por Maxim Gauci. Tamaño de la litografía: 72 x 53 cm. Año 1839.

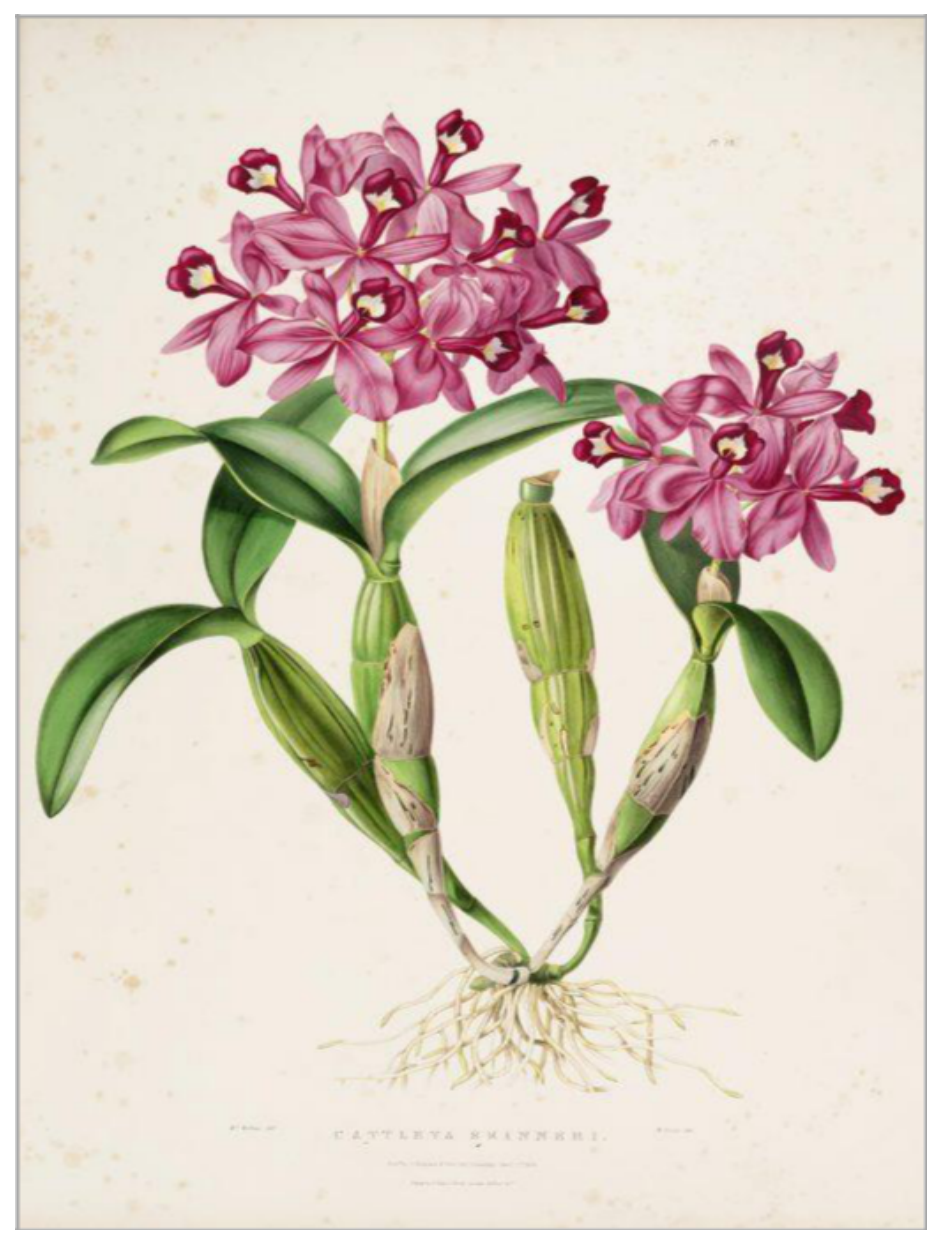

Fuente: Imagen de la Biblioteca Peter H. Raven, del Jardín Botánico de Missouri.

Skinner era un tipo querido y admirado por todos los coleccionistas, pues carecía de egoísmo y se entregaba en vida y alma a todas las causas, en especial por la colección de plantas, insectos y aves. En diciembre de 1866, viniendo de Inglaterra, arribó a Panamá. Su intención era finiquitar unos asuntos comerciales en Guatemala, y retirarse definitivamente en Inglaterra. Pero, aunque todas las vicisitudes y peligros de la tierra no habían podido con él, sí pudo un mísero mosquito infectado de "plaga americana". Enfermó y falleció en Aspinwall (Colón), el 9 de enero de 1867, a los 62 años, y fue sepultado en el cementerio de Mount Hope, donde reza su epitafio (el texto original está escrito en latín): 
[A la amada memoria de George Ure Skinner, F.L.S. (Fellow of the Linnean Society), nacido en Escocia, quien, cuando había cruzado los océanos treinta y nueve veces y estaba a punto de ir a Guatemala, fue llamado por un Dios misericordioso, del océano terrenal a un cielo placentero, el 9 de enero de 1867. R.I.P. Benditos los puros de corazón, porque ellos verán a Dios. Gracias sean dadas a Dios] $]^{13}$.

\section{La guaria morada es una flor maya}

Aunque la guaria morada es la flor nacional de Costa Rica y se suele asociar más con nuestro país que con otras regiones, lo cierto es que ella es una legítima flor maya, una flor inmigrante, cuyas raíces proceden del sureste de México (Chiapas), con una distribución desde México hasta Panamá.

Guarianthe skinneri (nombre científico actual de la guaria morada) es característica del Soconusco (Chiapas), la región más sureña y fronteriza con Guatemala, y su flor tiene un valor ceremonial en Mesoamérica (Coutiño-Cortés, 2018). Soconusco es una región donde han habitado los mames (etnia maya "Mam"), y según Coutiño-Cortés y otros "es posible que G. skinneri haya sido empleada ornamentalmente y para algún tipo ceremonial en épocas anteriores a la colonización española". Agregan que los mames llegaron a colonizar el Soconusco durante los siglos III y IV de nuestra era, y que ellos y otras:

\footnotetext{
"poblaciones prehispánicas en México apreciaban y empleaban las orquídeas como flores ceremoniales". Por lo tanto, "es probable que estas costumbres hayan trascendido la colonización y la evangelización católica española durante la conquista y que [así] permanezca hasta la actualidad".
}

En Soconusco, cuya gobernación fue pretendida por el mismísimo Miguel de Cervantes, en $1590^{14}$, la flor se conoce con el nombre de "Flor de la Candelaria", pues su época de floración coincide con la fecha de la fiesta de la Virgen de la Candelaria (2 de febrero), y se usa para adornar los altares ceremoniales. Ejemplos de ello, en dicha población, son las celebraciones en Tuxtla Chico, a pocos kilómetros de Tapachula, y también en el municipio Cintalapa de Figueroa.

\footnotetext{
13 Texto con su respectiva traducción: aporte de don Carlos Ossenbach Sauter.

${ }^{14}$ En el Prólogo de la primera parte de don Quijote de la Mancha, Cervantes cuenta que "engendró" el Quijote en la cárcel. Allí fue a parar el célebre escritor en el año 1597, por irregularidades en el manejo de unas cuentas de dinero público. La solicitud de Cervantes al rey Felipe II, siete años antes, era para ocupar la "Contaduría del nuevo reino de Granada, Contador de las galeras de Cartagena, Corregidor de la ciudad de la Paz, o bien gobernador de la provincia de Soconusco, en Guatemala". Ninguno de los cargos le fue conferido, por lo que el Quijote fue "engendrado" en una cárcel de Sevilla. De lo contrario, la famosa novela pudo haber nacido en América y no en España. https://www.jornada.com.mx/2005/01/14/a04n1cul.php
} 
La misma festividad se realiza en Guatemala, en el municipio de Jacaltenango, con la "flor de la Candelaria" como flor ceremonial y ornamental. En Guatemala, antiguamente se conocía como "flor de San Sebastián" a la forma alba de G. skinneri, pues también coincide su período floral con el 20 de enero, día de la fiesta de este santo (Torres, 2019).

\section{La guaria morada en Costa Rica}

\section{¿Por qué la llamamos guaria?}

En la introducción del Diccionario de Costarriqueñismos de Arturo Agüero Chaves (1996), el autor ofrece una lista de voces del español de Costa Rica, cuya etimología, según Agüero, no está bien definida; pero que bien pudieron originarse de lenguas indígenas nacionales ya desaparecidas, y entre ellas cita la palabra guaria. Por su parte, el diccionario de costarriqueñismos de Carlos Gagini (1919), refiriéndose al origen de la palabra, indica que "Hay en las Antillas unos indios llamados guariados o manchados, palabra que según Macías ${ }^{15}$ es la castellana variados; en tal caso nuestro guaria no sería voz indígena, como supone Pittier, sino la española varia". Por lo tanto, según Gagini, creyendo en Macías y desoyendo a Pittier, el participio guariado viene siendo una corrupción de variado (o sea que el verbo "guariar" da origen a la palabra "variar", y que guaria no es más que varia). Revisando el libro de Henry Pittier del que habla Gagini (Pittier, 1908, p. 99), el científico suizo, en la etimología de la palabra guaria señala que "el nombre es indígena". No lo supone, como dice Gagini, sino que tajantemente afirma que guaria es nombre indígena de Costa Rica.

Nos intrigó mucho que Gagini se adhiriera a la explicación extranjera de la palabra y desaprobara su origen autóctono, por lo que hicimos la consulta al Dr. Miguel Ángel Quesada Pacheco, lingüista y lexicógrafo ${ }^{16}$. Nos respondió que "La palabra guaria parece que solo en nuestro país se usa, de modo que hay grandes posibilidades de que sea de origen indígena $y$, por qué no, huetar"17.

15 José Miguel Macías, prestigioso filólogo y lingüista cubano (1832-1905). Más información en: https://www.ecured.cu/Jos\%C3\%A9 Miguel Mac\%C3\%ADas

${ }^{16}$ El Dr. Miguel Ángel Quesada Pacheco, Premio Nacional de Cultura Magón (2014), es una de las voces más respetadas de nuestro país en estudios lingüísticos acerca del aporte de las lenguas autóctonas al español de Costa Rica, https://www.nacion.com/viva/cultura/miguel-angel-quesada-pacheco-maestro-de-lalinguistica/LUGTPY6E25HRLKH6NY2NOVU7LE/story/

17 Comunicación personal con el autor. 
En cuanto a la posición de Gagini, Quesada opina que el famoso maestro tenía la tendencia a prestar atención y acudir a raíces o palabras foráneas para descubrir o explicar éticos puramente costarricenses, lo que no siempre era necesario y, en algunas ocasiones, inconveniente. Probablemente sea este otro ejemplo de ello. Agrega don Miguel Ángel que en el Diccionario de la Lengua Española (de la RAE), no figura el verbo "guariar", y a lo que más se llega es a la palabra:

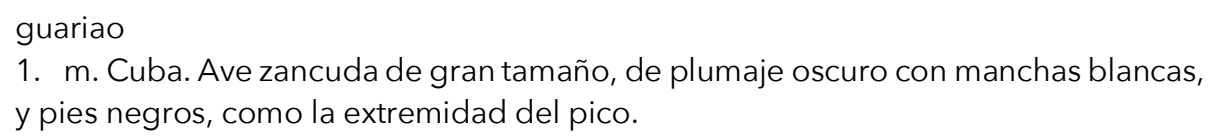
y pies negros, como la extremidad del pico.

Por su parte, el mismo Diccionario de la Lengua Española (DLE) indica que la palabra guaria es usada también en Honduras. Sin embargo, es oportuno que en un futuro se realice un estudio que sirva para constatar su uso en el hermano país, pues varias consultas que hicimos a ciudadanos hondureños, entre ellos, ingenieros agrónomos y expertos en orquídeas, nos indican desconocer dicha palabra, en referencia a esta orquídea.

Circulan otras explicaciones del origen de la palabra guaria. Por ejemplo, Dobles-Segreda (1945) indica que la raíz "gua" es indígena y significa árbol, y por ello muchos nombres de árboles que empiezan con esa raíz son indígenas (ej. guayacán, guanábana, guayabo, guachipelín, guarumo, etc.); sin embargo, esta explicación, aunque pudiera contener verdad, actualmente carece de estudios científicos que la respalden.

En conclusión, a reserva de que en algún momento surja un estudio lingüístico del origen de la palabra guaria, basados en la literatura disponible y en la consulta hecha a expertos, opinamos que guaria es, con alta probabilidad, una voz indígena costarricense (¿acaso huetar, como sugiere Quesada?).

\section{Del bosque a la tapia entejada}

Cuando en nuestro pequeño territorio aún no había aborígenes, y tan solo se escuchaba el rugido holgazán del jaguar y el canto pasional de las aves, la guaria morada era la reina de los bosques. En los meses de febrero y marzo, miríadas de abejas sucumbían trastornadas por la intensa luz violácea de aquella flor que llegó a nuestra tierra por la vía maya, impulsada por el viento, el agua, y el loco frenesí de sus polinizadores. 
Luego aparecieron nuestros aborígenes, y la guaria los recibió con sus hermosos pétalos abiertos. Posteriormente vino la Conquista, y el dios del Viejo Mundo, más su legión de santos y vírgenes, sustituyeron a los dioses autóctonos, y la guaria empezó a ocupar un sitio en los nuevos ritos. Resulta muy tentador extrapolar el uso ceremonial de las orquídeas (y obviamente, de la guaria morada) del mundo maya a las culturas aborígenes en Costa Rica; sin embargo, para este artículo no encontramos estudios que evidencien el uso ceremonial u ornamental de Guarianthe skinneri por parte de nuestros indígenas. La Dra. María Eugenia Bozzoli, antropóloga y Premio Nacional de Cultura Magón (2001), cree que difícilmente ocurrió este fenómeno en Costa Rica, y pone por ejemplo el caso de los bribris, que no suelen traer flores del bosque a sus casas, por el respeto que sienten hacia todos los elementos del bosque, aunque sí recogen plantas para uso medicinal o alimenticio, previa solicitud de permiso a la montaña ${ }^{18}$.

Al iniciarse la segunda mitad del siglo XIX, la guaria morada ya era flor mimada del pueblo, y como hoy, constituía el orgullo de los campesinos que adornaban las tapias entejadas y corredores de sus casas con la humilde florecita nazarena, ignorando que dicha práctica encerraba el germen de su exterminio, y poco a poco, la flor empezó a desaparecer de su estado natural. Hoy prácticamente ya no se encuentra en nuestros bosques y montañas. El botánico del Jardín Lankester, Diego Bogarín, señala que la guaria "crece como epífita en ramas de árboles y ocasionalmente en rocas volcánicas, como cerca de los volcanes Cacao, Orosi, Miravalles y Rincón de la Vieja. Pero ya en esta época es muy difícil observarla en la naturaleza."19. El Arq. Carlos Ossenbach agrega que

\footnotetext{
"en términos generales se encuentra (o encontraba) en estado silvestre en las laderas del Pacífico de nuestras cordilleras, a unos 200 a 900 m.s.n.m. Para su crecimiento natural, la guaria requiere dos estaciones (seca y lluviosa) bien definidas y equilibradas y un clima en general relativamente caliente. Como ejemplos típicos mencionaría Orotina, Turrubares, Atenas, etc. [Agrega que] La guaria no es nativa de Cartago, ni de las partes altas del Valle Central. Ciertamente, se ha logrado aclimatar en lugares más fríos que aquellos en los que se originó. Por ejemplo, una de sus tierras favoritas es la zona de Orotina, con estaciones bien marcadas, y con largos períodos secos que favorecen su floración. De igual forma debe considerarse una licencia poética el verso de la canción "La guaria morada" en el cual dice que adorna las quebradas, "donde son los montes fríos y están las aguas heladas". Ciertamente no son los montes fríos ni las aguas heladas lugares en los que se encuentre la guaria morada". ${ }^{20}$
}

\footnotetext{
18 Entrevista con el autor, fecha: 10 de septiembre de 2019.

19 Entrevista con el autor, fecha: 2 de abril 2019.

${ }^{20}$ Entrevista con el autor, fecha: 11 de abril 2019.
} 
Ahora bien, ¿contradice esta explicación de Ossenbach lo narrado por Mario Sancho acerca de las guarias sobre los techos de las casas en el Cartago preterremoto, considerando que esta planta no es nativa de Cartago ni de las partes altas del Valle Central? Pensamos que no objeta a don Mario, antes bien complementa su visión, puesto que muy posiblemente, aquellas guarias eran colocadas por la mano de los cartagineses, sobre los techos entejados de sus casas, donde la agradecida planta se aclimataba sin mucha resistencia.

A inicios del siglo $X X$, la guaria crecía y multiplicaba su espacio en nuestros bosques. Henry Pittier, en 1919, indicaba que la guaria

"corona los muros de los patios y los techos de muchas casas antiguas en Cartago y alrededores, en donde parece haber sido una favorita desde los tiempos más remotos: hasta es posible que lo haya sido de los Indios, cuyas mujeres gustan adornarse la cabeza con las grandes flores rosadas" (Pittier, 1919, p. 99).

Por su parte, el renombrado científico costarricense, Anastasio Alfaro, en el año 1924, comentaba que era tal la abundancia de la Cattleya skinneri en nuestro territorio que

\footnotetext{
"la mayor parte de los jardines y casas de campo en la Meseta Central, presentan el gracioso atractivo de estas, colocadas al aire libre, sobre troncos vivos de poró. Y lo que es más simpático aun, es ver a nuestras jóvenes campesinas luciendo ramos de guarias en el pecho, como pudieran hacerlo las damas más encopetadas de la nobleza británica" (Alfaro, 1924 p. 40).
}

Asimismo, muchos viajeros europeos del siglo XIX contemplaron, extasiados, el esplendor de orquídeas y guarias moradas en su estado natural, y dejaron descripciones absolutamente brillantes, entre ellos: Friedrich Wilhelm Adolph Marr, y Karl Albert Ludwig von Seebach, de Alemania; Frederick Boyle y Thomas Belt, de Inglaterra; y Thomas Francis Meagher, de Irlanda.

Finalmente, el suizo Ricardo Pfau, quien tuvo una importante jardinería en San José, en las últimas décadas del siglo XIX, publicó en 1895 una curiosa obra: New, Rare and Beautiful Orchids of Costa Rica, and How They Grow at Home ${ }^{21}$. En esta obra, que aunque no era de carácter científico, fue la primera publicada en Costa Rica acerca nuestras orquídeas. De la guaria morada, dice lo siguiente:

21 Se puede descargar una copia del libro en esta dirección: http://epidendra.org/LITERATURE/Pfau\%201895/lit.html 
Cattleya skinneri - Una bella especie, que florece libremente. Aquí, en las tierras altas, florece de febrero a abril, y en tiempo de Pascua, durante la Semana Santa, muchas de las bellas muchachas costarricenses adornan sus pequeños sombreros de paja con las largas inflorescencias de la guaria morada, cuyo brillante color de rosa presenta un admirable contraste con el delicado y blanco cutis de estas hijas de la Suiza tropical... era hace unos diez años una orquídea común en toda Centroamérica, pero en los últimos años se han exportado cargamentos enteros y hoy en día, al menos en Costa Rica, se ha convertido en una especie casi rara. (Ossenbach, 2016).

Figura 4. Guarias moradas en un árbol de Barva de Heredia, con probable intervención humana

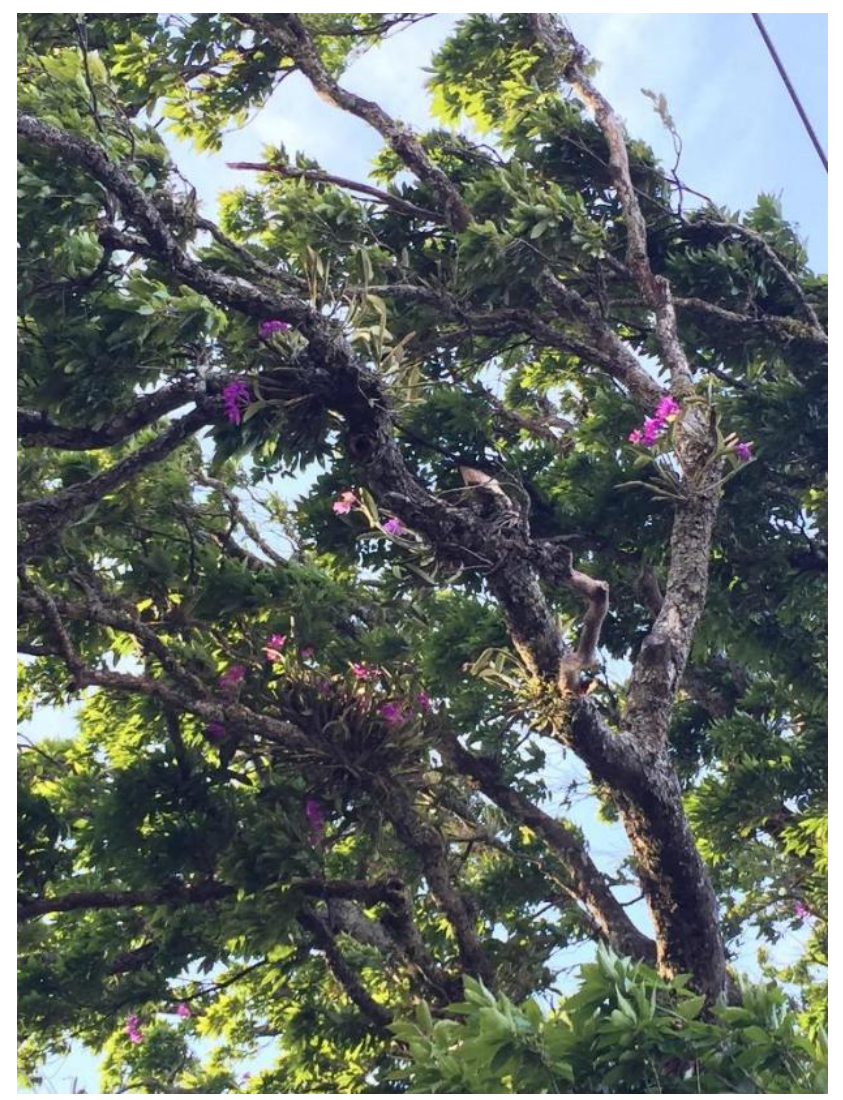

Foto cortesía de Diego Bogarín, Jardín Botánico Lankester, UCR.

\section{La guaria morada estrena nombre}

El nombre científico de la planta (Cattleya skinneri) permaneció inalterado, desde el bautizo hecho por Bateman en 1839, hasta el año 2003, cuando la guaria morada estrenó un nuevo nombre: Guarianthe skinneri. Solo cambió el nombre de pila, pero se conservó y se conservará para siempre su noble apellido, en honor a su célebre descubridor. 
Durante una investigación efectuada en el año 2000 en la Universidad de Reading, Inglaterra, se analizó el ADN de un grupo de orquídeas de Centroamérica, y gracias a ello se demostró que la guaria no pertenece al género Cattleya, como se creía desde la época de Cattley, Bateman y Skinner.

Los expertos propusieron agregar la guaria morada al género Rhyncholaelia, que posee características muy similares. Por fortuna, dos científicos estadounidenses se opusieron a la idea. El biólogo Robert L. Dressler ${ }^{22}$, del Jardín Botánico de Missouri, Estados Unidos y su colega Wesley E. Higgings de los Jardines Botánicos Marie Selby, Sarasota, Florida- intervinieron para evitar que la planta fuera incluida en dicho grupo.

"Aunque hay algunas similitudes, se trata de un grupo diferente, y nosotros consideramos que debía buscarse un nuevo nombre que fuera razonable y agradable", manifestó Dressler para un artículo del periódico La Nación (Martínez, 2003) y agregó que "La guaria morada tiene dos hojas y una flor mediana, mientras que el género Cattleya se caracteriza por tener una sola hoja larga en cada bulbo y una flor mucho más grande".

Para rebautizar el género de la flor nacional, dice el artículo, se valoró el de Candelaria (por ser este el nombre común en Guatemala para esta planta); pero pronto fue descartado, porque ya existe un liquen llamado así. Finalmente, como ella es la flor nacional de Costa Rica, decidieron otorgarle un nombre acorde con la idiosincrasia costarricense, y se optó por Guarianthe skinneri. En griego, anthos significa flor, y el prefijo guaria se eligió, porque los ticos empleamos esa palabra para referirnos a esta orquídea, y por lo general a todas las orquídeas (Martínez, 2003).

El Dr. Dressler anunció el nuevo nombre de la flor nacional, durante el Primer Congreso Internacional de Orquideología Neotropical celebrado en la Universidad de Costa Rica, el jueves 22 de mayo de 2003, y se dio a conocer en la revista Lankesteriana (Vol. VII, 2003), una publicación del Jardín Botánico Lankester de la UCR ${ }^{23}$.

${ }^{22} \mathrm{https} / / /$ es. wikipedia.org/wiki/Robert Louis Dressler

${ }_{23}$ La revista científica Lankesteriana es una publicación del Jardín Botánico Lankester, de la Universidad de Costa Rica, dedicada a la publicación de artículos relacionados con la ecología, anatomía, fisiología e historia de las orquídeas. Más información en: https://revistas.ucr.ac.cr/index.php/lankesteriana/about 


\section{Crónicas de guaria}

\section{La guaria más increíble del mundo salió de Cartago}

La revista inglesa The Gardeners' Chronicle (1884) cuenta la fantástica historia de una monstruosa macolla o masa de Cattleya skinneri (hoy Guarianthe skinneri), que cuidaba celosamente un campesino, en su pequeño terreno de Cartago (citado en Ossenbach, 2004). Aquel descomunal racimo de guarias pesaba más de 500 kilos y medía $2 \mathrm{~m}$ de ancho por casi $2 \mathrm{~m}$ de altura.

El artículo indica que la masa fue plantada hace muchos años por este campesino, en las ramas de un árbol de la especie euphorbia. La veló con esmero hasta que floreció bajo su cuidado y, con el tiempo, su jardín se convirtió en un sitio de interés para muchos visitantes, irresistiblemente atraídos por aquella exquisita floración. La fama de esta masa de guarias llegó a los oídos del mismísimo G. U. Skinner y -sin pensarlo mucho- visitó Cartago, donde quedó impactado con aquella maravilla, nunca antes vista. No se sabe si Skinner llegó aquí procedente de Guatemala, o fue cuando su nave naufragó en nuestras costas, en el frustrado viaje hacia Perú, pues la revista se limita a indicar que Skinner vio la fantástica masa de guarias, en su hábitat.

Benedict Roezl, explorador checo y famoso colector de orquídeas, contó más de 1500 flores en el racimo, en una visita que hizo a Cartago. Como era de esperarse, muchos viajeros y exploradores hicieron numerosas ofertas por la gigantesca mata de guarias; pero la respuesta siempre fue la misma por parte de su dueño: "no está en venta". Sin embargo, como se sabe, el dinero es sospechoso pero también doblega las carencias, y fue así como, en el año 1884, llegó a nuestro campesino una oferta irresistible, por parte del orquideólogo inglés Frederick Conrad Sander. De pronto, la macolla fue sacada de su hábitat, y para que no sufriera daño alguno, sus nuevos dueños decidieron cortar el árbol por encima y por debajo del colosal racimo. Colocada escrupulosamente dentro de una gran caja de madera, fue enviado en carretas hasta Puntarenas, y desde allí por el vapor de correo Royal Medway, hasta Southampton, Inglaterra. En su lugar de destino, St. Albans, Hertfordshire, la firma preparó un ambiente adecuado, suspendiendo del techo de un invernadero una enorme cadena, para sostener la colosal masa de guarias. 
Revista Herencia, Vol. 33 (1), enero-junio, 2020.

\section{Con gran asombro, la revista indicaba que:}

“Es ciertamente la masa más maravillosa de todas las orquídeas jamás importadas, y es probable que nunca se vuelva a obtener ningún otro espécimen de este tipo, ya que ninguno permanece en una sola masa (como esta) durante el número adecuado de años en vida silvestre.".

\section{También señaló que}

"Teniendo en cuenta la gran dificultad de importar, incluso pequeños ejemplares de esta planta, los Sres. Sander deben sentirse felices por su éxito. Nuestra ilustración muestra la planta "en casa", con su último dueño al pie, portando un hacha en la mano, a punto de talar el árbol".

Figura 5. llustración de la macolla de guarias del campesino cartaginés

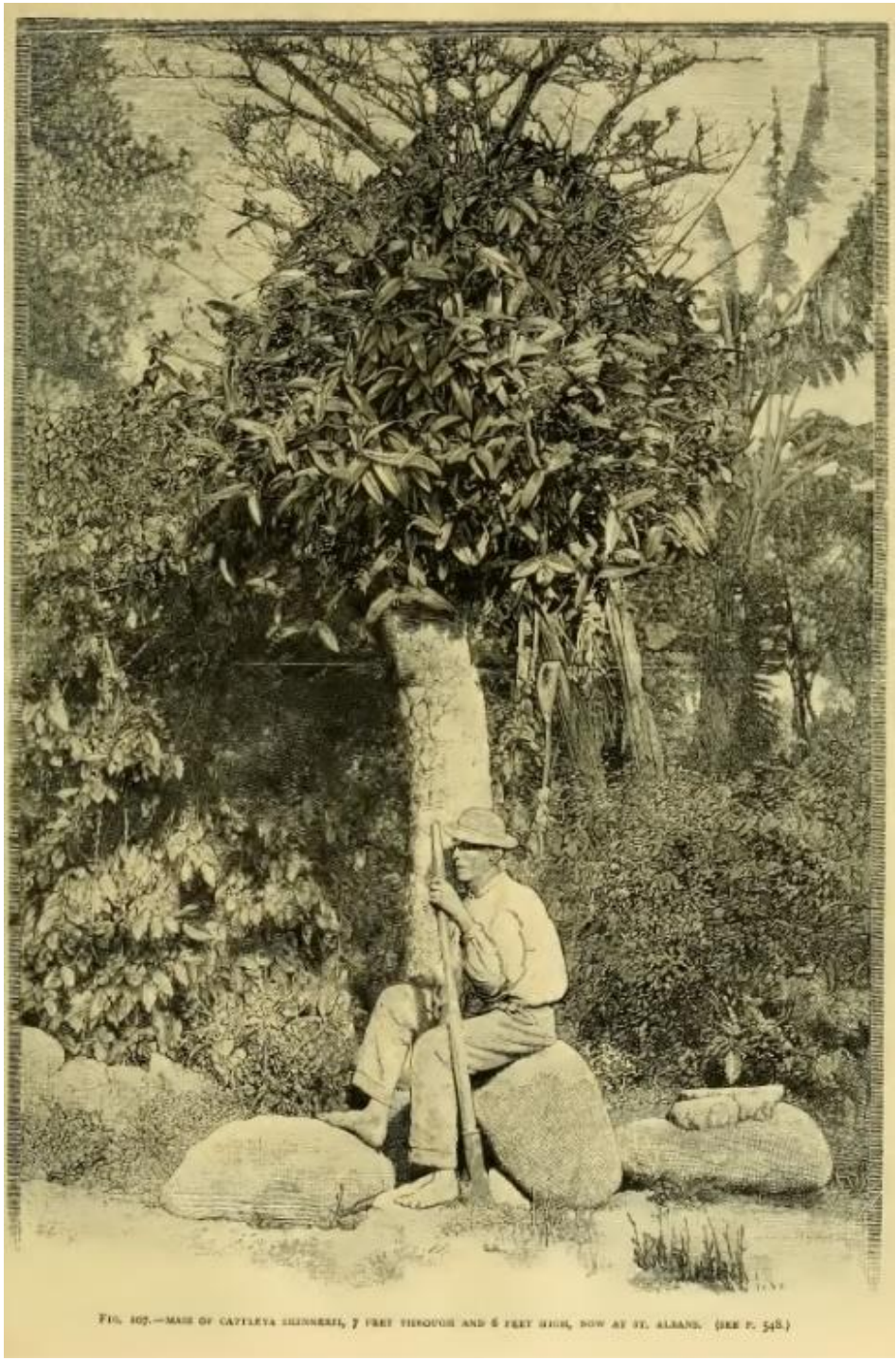

Fuente: Imagen publicada en The Gardener's Chronicle (1884) 
Pensamos que el último párrafo en The Gardener's es erróneo, primero porque el campesino no porta un hacha, sino una macana agrícola, y segundo porque los señores F. Sanders \& Co, difícilmente, habrían permitido que el hombre de la imagen (ya entrado en edad) se encargara, él solo, de talar el árbol, tratándose aquella de una compra sumamente delicada y costosa.

\section{Guarianthe skinneri "Danae"}

El Dr. Daniel Pizarro Torres ${ }^{24}$ es un médico costarricense que se dedica a la reproducción de orquídeas, desde hace más de 50 años. Con él hablé varias veces durante la preparación de este artículo, y entre muchas cosas interesantes acerca de las orquidáceas, me contó una maravillosa historia de la guaria morada, que procedo a narrarles de inmediato. En marzo de 1975, según él recuerda, una señora de Escazú, doña Danae Brenes de Brenes, produjo un hito en la historia de la guaria morada en Costa Rica. Doña Danae amaba las plantas y tenía muchas en su jardín, pero no sabía nada de orquídeas, al punto que al llegar la primera matita de guaria a sus manos, decidió sembrarla en una maceta con tierra, de la misma forma que sembraba todas sus plantas. Como sabemos, las guarias son epífitas y sus sustratos comunes son las piedras, las tejas, las ramas de árboles, etc. Nadie le advirtió a doña Danae que no se siembran en tierra. "Una mata es una mata, y a la tierra escazuceña con ella", pensó la señora de esta historia.

Aunque aterrada en aquella maceta, la guaria de doña Danae se sintió bien, y empezó a crecer muy segura, evidentemente contagiada por la felicidad de todas las matas del jardín, y con el tiempo vino a dar unas exquisitas guarias. Nadie pasaba indiferente ante aquel tesoro de doña Danae, y pronto alguien la convenció de llevar su preciosa mata a la $5^{a}$ Exposición de la Sociedad Orquideológica de Costa Rica, en la sede del Instituto Nacional de Seguros, frente al Parque España. A la exposición asistieron jueces de la American Orchid Society (http://www.aos.org/), que es la organización mundial por excelencia, en el tema de las orquídeas.

\footnotetext{
${ }^{24}$ El Dr. Pizarro (1932) es pediatra, exjefe de Emergencias del Hospital Nacional de Niños. Fue asesor en rehidratación oral para la Organización Mundial de la Salud (OMS) y miembro fundador de la Academia Nacional de Medicina de Costa Rica; también forma parte de la Academia Nacional de Ciencias de Costa Rica, de la New York Academy of Sciences, y de la American Orchid Society. Sus investigaciones en medicina se han publicado en prestigiosas revistas, incluidas Lancet y New England Journal of Medicine.
} 
Para sorpresa de todos, los jueces juzgaron como "excepcional" la guaria sembrada en tierra de doña Danae, y la premiaron con una puntuación superior a 8. Fue tan asombrosa para los jueces aquella guaria que la bautizaron con el nombre de Cattleya skinneri "Danae" (hoy Guarianthe skinneri "Danae"). La declaración de los jueces indicó que la "Danae" se destacaba por tener "Cincuenta y ocho flores excepcionalmente bien formadas, con segmentos anchos y textura brillante. Seis bulbos. Las flores son más oscuras que el promedio, de color lavanda, labelo muy marginado con la garganta color crema" 25 .

Don Daniel, que conoció a doña Danae, le dio el consejo de dividir correctamente la planta para que no se perdiera la esencia de sus futuros hijos; le dijo: "Doña Danae, lo recomendable para reproducir una orquídea como las guarias, es que la que va a ser nueva planta, debe tener un mínimo de tres bulbos". Pero doña Danae, como novicia en orquídeas que era, no interpretó bien el consejo, y cortó tres bulbos de la planta original por separado. Lo curioso es que cada bulbo respondió como si fueran tres, y todos lograron sobrevivir, porque la mano ágil y cálida de doña Danae hizo su mejor parte en aquella feliz permuta botánica. Uno fue llevado a los Estados Unidos, donde reprodujeron la "Danae", mediante la técnica de meristemo ${ }^{26}$; pero, sorprendentemente, en el proceso de cultivo, sucedió una inesperada mutación de la planta, que cambió en su estructura. La planta fue cultivada en California, en un vivero llamado Carpintería, y la mutación, para asombro de todos, dio origen a una guaria morada superior a la "Danae". La orquídea fue expuesta en el vivero, y los jueces llegaron a afirmar que aquella era la mejor guaria de todo el mundo (¡la nieta de la matita enterrada de doña Danae!). Finalmente, no se supo de dónde sacó doña Danae la maravillosa planta.

\footnotetext{
25 Traducción del inglés al español por Daniel Pizarro Torres.

${ }^{26}$ Meristemo es una forma de reproducción artificial de las plantas. En este caso, la orquídea, conforme crece, va reproduciendo células madre en la punta de sus bulbos; dichas puntas se cortan y a partir de ellas se realiza un cultivo, del cual deriva una nueva planta, que será una especie de clon de la original (explicación dada por el Dr. Daniel Pizarro al autor).
} 
Figura 6. Foto de la guaria morada en maceta con tierra que llevó doña Danae de Brenes a la exposición

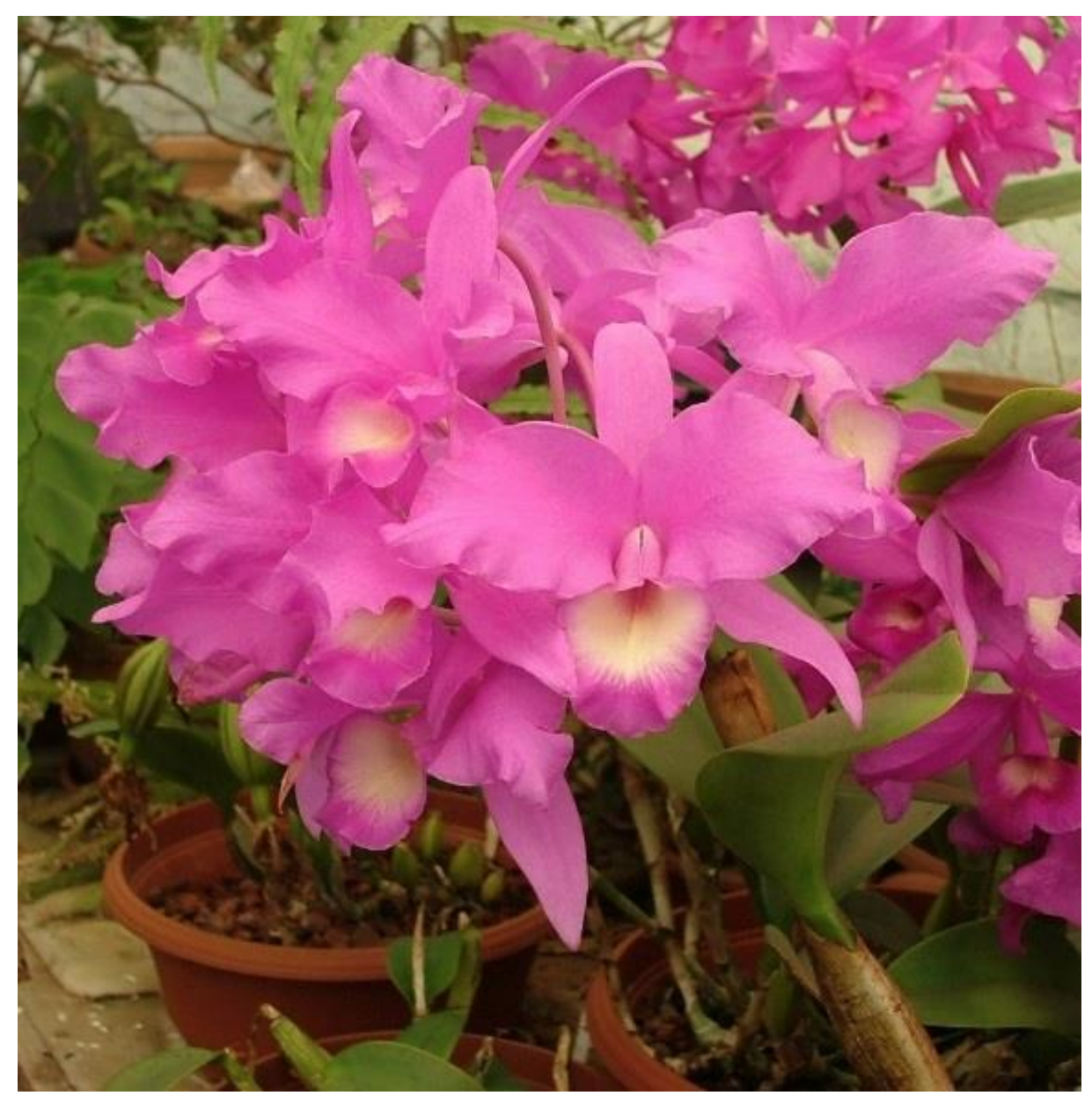

Fuente: Propiedad de American Orchid Society (1975). Cortesía de Daniel Pizarro Torres.

\section{Crecen las guarias en el Cementerio General de San José, una visita a Mr. Lankester}

Ruth Dowell Svihla (1897-1974), destacada botánica de la Universidad de Washington, visitó Costa Rica en 1945, y producto de sus experiencias en nuestro país, publicó un estupendo artículo en la Revista del Instituto de Defensa del Café de Costa Rica. El artículo se titula: "Coleccionando orquídeas 
en Costa Rica"27. En él, la Dra. Dowell narra su experiencia en la búsqueda de orquídeas y, mientras se lamenta de la forma en que las plantaciones de banano y las carreteras han invadido las selvas primitivas, provocando la muerte de miles de árboles, y con ellos la desaparición de preciosas orquídeas, también indica que

"tal vez la mejor manera de salvarlas sería coleccionando y propagando estas especies en lugares en que estarían salvas de la destrucción, algo así como lo que se ha hecho con algunas de las orquídeas indígenas de los Estados Unidos, que estaban en el mismo caso".

Visitó varios sitios relacionados con el cultivo y conservación de estas plantas, entre ellos el herbario de orquídeas del Museo Nacional, los jardines del señor Clausen (La Mil Flor), donde destacaba la primorosa Cattleya dowiana (guaria de Turrialba), las colecciones de don Alex Cohen y de don Alberto Pérez, etc. Nos cuenta Dowell que

"en los ratos libres paseábamos por el Paseo Colón admirando las canastas de Stanhopea (toritos) y Cattleya (guarias) colgando de los corredores. ... Los árboles de los parques se veían todos cubiertos de helechos y con grandes festones de orquídeas de varias especies".

Evidentemente, la guaria morada aún era frecuente en aquellos paisajes en la década de 1940, pues la doctora Dowell indica que es

“...muy común ver orquídeas, especialmente Cattleya skinneri encaramada en las cúspides de las catedrales y agarradas a la mampostería. ¡Dios sabe cómo! Otras veces, y vimos muchas, sobre las tejas que cubren las tapias de adobe de patios y huertos".

Familiarizados con la guaria sobre techitos, tapias y corredores, de pronto la Dra. Dowell nos invita a buscarla en las alturas, hasta encontrarla, insolente y furtiva, en las paredes descosidas de iglesias o en la misma cúpula: habitáculo común de palomas, pero no de una flor tan bella. Y si ya les parece atrevida la guaria remontando a estos improbables rincones, ¿no les aterra su suprema osadía de alcanzar la morada final de los muertos? Así lo describe la Dra. Dowell: "En el Cementerio mismo, la Catlleya skinneri (guaria morada) crecía sobre los mausoleos, completamente expuesta al sol y al agua".

27 Fue publicado originalmente en inglés, en la revista "Orchidologia zeylanica: the Ceylon orchid review", según se indica al inicio del artículo. 
Finalmente, la doctora visitó la hacienda Las Cóncavas, en Cartago, perteneciente a don Carlos Lankester ${ }^{28}$, de cuya experiencia nos ofrece una narración tan espléndida, que nos parece reminiscente de "La Gran Estufa" de Joseph Paxton.

\footnotetext{
"En visita a los jardines de don Carlos Lankester, después de un té muy inglés y muy refrescante, nos dedicamos a recorrer los jardines. Admirando aquellos jardines literalmente atestados de orquídeas... Cada árbol era un albergue de incontables especies. Después, más y más jardines hasta llegar, ya muy entrada la tarde a un huerto en el que de las ramas de todos los árboles colgaban más y más orquídeas".
}

Lo malo es que aquella fue la época del más radical saqueo de orquídeas en Costa Rica, donde llegaban a los mercados de nuestro país -así lo narra Dowellcentenares de carretas repletas de toritos, cattleyas, guarias, vandas, y tanto nacionales como extranjeros, se apoderaban de miles de ellas, con la diferencia que la doctora se llevó las plantas para estudio, reproducción y propagación de la especie.

\section{El árbol de guarias de Alajuela}

El 21 de enero de 1915, don Gurdiano Corrales González, le compró a don Jacinto Rojas Arroyo un inmejorable terreno cultivado de café, caña de azúcar y pastos, en el centro de la ciudad de Alajuela. La finca llevaba por nombre "La Esperanza", medía 96000 m2, y el negocio se transó en 9750 colones, como quien dice a 10 colones el metro. Cuando se hizo la venta, el gran árbol de cenízaro estaba allí, y seguramente ya era centenario. Era como el cuidador de la finca, y en aquella época, albergaba más de 30000 guarias en sus extensas ramas. "Nunca se le sembró una guaria, solas se fueron reproduciendo y decía mi abuelo que ya el árbol existía desde que Alajuela (hoy la gran ciudad) era toda una montaña", testimonia don Humberto Corrales Vargas, nieto de don Gurdiano29, en un texto escrito por él en el año 1979.

${ }^{28}$ Charles Herbert Lankester. Nació en Southhampton, Inglaterra, en 1870. Estudió fotografía en el Instituto Politécnico de Londres y llegó a Costa Rica en el año 1900. Trabajó para varias empresas cafetaleras, y luego se interesó en el estudio y colección de aves y mariposas; pero las plantas, y en especial, las orquídeas fueron su especialidad. Falleció en el año 1969, dejando un enorme legado en la producción y conservación de las orquídeas. Gracias al esfuerzo conjunto de la American Orchid Society y de la Stanley Smith Horticultral Trust, el jardín de "don Carlos" en Cartago, fue comprado y donado por estas organizaciones a la Universidad de Costa Rica, el 2 de marzo de 1973. El jardín botánico, ubicado en Paraíso de Cartago lleva el nombre del naturalista.

${ }^{29}$ Humberto Corrales Vargas, "Una tradición alajuelense", 1979. 
En 1941, don Gurdiano, que ya poseía otras fincas, decidió heredar el terreno del Árbol de Guarias a su hijo Humberto, recién casado con doña América Vargas Herrera. Frijoles, café, caña, maíz y pastos era lo que producía aquel fértil terreno. Del matrimonio de don Humberto y doña América nacieron seis hijos, que vivieron en la finca junto al famoso árbol.

De acuerdo con el testimonio de don Humberto y de su hermana doña Dunia, los años de plenitud y florecimiento de guarias en el gran árbol fueron las décadas de 1950 a 1980. Su fama trascendió las fronteras. "Extranjeros y nacionales, en febrero y marzo de cada año, desfilaban para presenciar aquel majestuoso altar, que se deshacía de todas su hojas, para que el visitante deleitara más su vista al apreciar las guarias en toda su intensidad", escribe don Humberto. Asimismo, él recuerda que un día el famoso árbol recibió la visita del mismísimo presidente de la República, don Francisco J. Orlich, acompañado de su esposa, doña Marita Camacho.

Cuando eran niños, a los hermanos Corrales Vargas les tocaba abrir los portones de la finca para que los visitantes llegaran hasta el Árbol de Guarias; enseguida, eran retribuidos con alguna moneda o billetillo. Aquel fantástico árbol era como una aurora boreal en el bosque de Alajuela, y en el año 1952, el pintor Julio Solera, arrebatado por su fulgor, le hizo la primera pintura.

Dos años después, hacia 1954, el joven costarricense Alberto de Goeyen (19311980), inició el rodaje de un documental cinematográfico, titulado "El atardecer de un fauno". Según lo indica su hermano John de Goeyen (La Nación, 22 agosto de 2000), Alberto "se inspiró en el poema Atardecer de un Fauno del francés Stéphane Mallarmé (1842-1898) y adoptó para ello la música del compositor Claude A. Debussy (1862-1918) -la segunda inspirada en el primeropara su película". El Centro de Cine del Ministerio de Cultura, en su página Fondo El Fauno informa que, lamentablemente, el autor no logró ver en pantalla su realización, pues perdió la vida antes, víctima de enfermedad. Según datos de la familia de don Gurdiano, Alberto de Goeyen encontró inspiración e imágenes oportunas y fantásticas en el famoso Árbol de Guarias de Alajuela, y lo filmó como elemento de atracción, durante varias sesiones. Lamentablemente, se desconoce el paradero del filme, como de muchas otras películas que recogieron la Costa Rica de antaño. 
Para el Año 1984, aquella cantidad de guarias era sumamente tentadora para los vándalos, quienes un día ultrajaron el precioso altar de la flor nacional, y se llevaron infinidad de plantas, para conmoción de los alajuelenses. Con el tiempo, sus ramas fueron perdiendo consistencia. Muchas se desplomaron, y como el árbol ya estaba muy viejo y había perdido el vigor y el encanto de las guarias, es decir, su esencia misma, la familia de don Gurdiano decidió repartir las plantas que quedaban entre sus familiares. Finalmente, al árbol le llegó su hora aciaga, cuando en el año 1994 se empezó a urbanizar la propiedad. De él solo queda el nombre en la "ASADA Árbol de Guaria", de dicha comunidad ${ }^{30}$. El terreno se ubica 100 metros al sur de la Antigua Comandancia, sobre la "Calle Ancha", hoy Urbanización Baviera.

Figura 7. Árbol de Guarias, hacia el año 1980

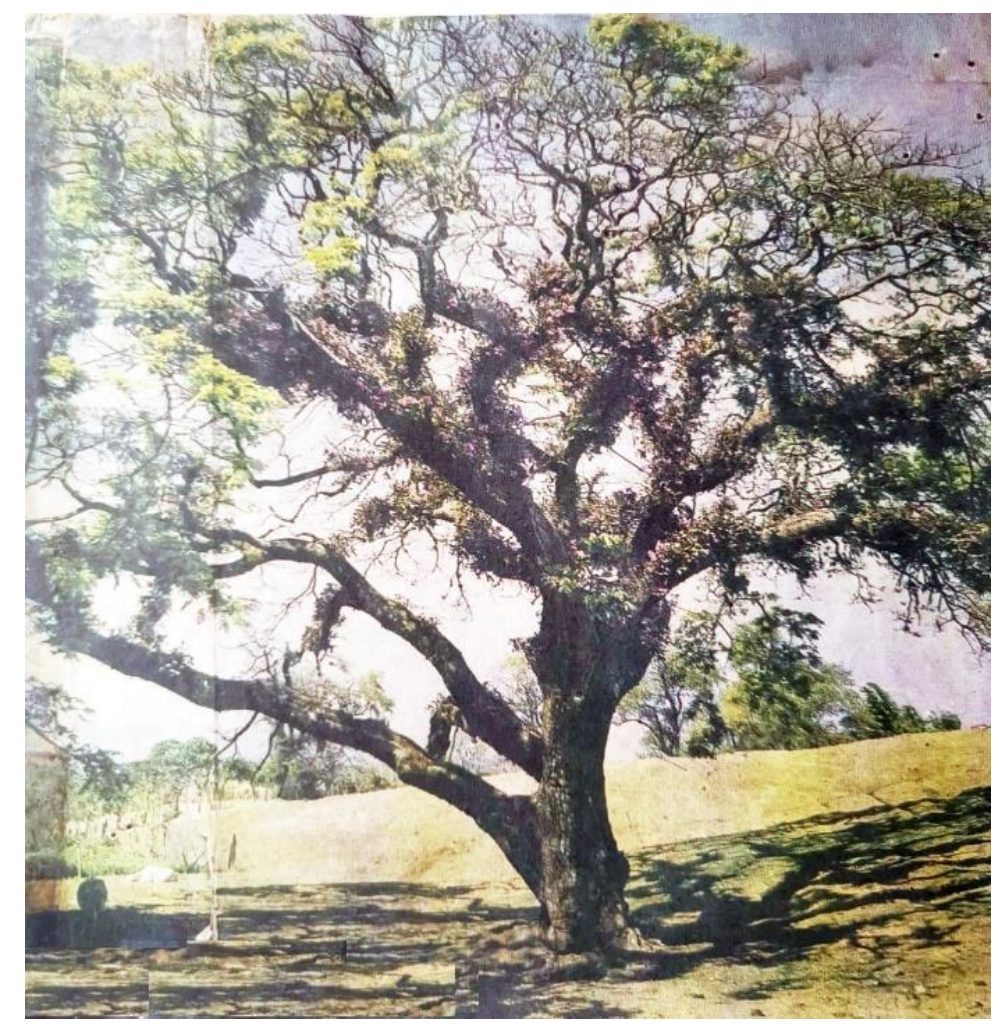

Fuente: Foto propiedad de familia Corrales Vargas

${ }^{30}$ Ver: http://www.asadaarboldeguaria.com/ 


\section{Colofón}

Hemos emprendido una brevísima travesía por los encantadores senderos de la guaria morada y por la fascinante vida de algunos de sus ilustres apasionados. Por tanto, el presente artículo constituye apenas un leve estímulo para el estudio futuro de este grandioso símbolo nacional, estudio aún no emprendido en su conjunto. Sin embargo, no podemos finalizar sin una pregunta obligatoria: ¿de qué factores depende su futuro y qué podemos hacer las personas comunes por ella? Su futuro pasa, en gran parte, porque las personas comprendan su fragilidad, así como por la urgencia de evitar su "propagación artesanal", es decir, la venta de individuos capturados en el bosque, con el único propósito de la simple reproducción lucrativa.

El Jardín Botánico Lankester, de la Universidad de Costa Rica, como el organismo preponderante en el estudio de las orquídeas en nuestro país, está planeando propagar individuos silvestres de la guaria morada y realizar un estudio para reintroducirla en su hábitat natural, así como un programa de estudios genéticos. También disponen de un plan para concienciar a la población de no perturbar las poquísimas poblaciones naturales de orquídeas, y para que las personas, idealmente, solo adquieran plantas propagadas en laboratorio.

¿Qué más podemos hacer las personas para ayudar en esta lucha? Lo más importante es no comprar guarias a vendedores de la calle, en su lugar, aproveche las exposiciones de orquídeas y pregunte a los expertos y cultivadores, quienes seguramente lo asesorarán acerca de la mejor forma de adquirir y cuidar una planta.

Queda pendiente, próximamente, la publicación del artículo complementario (en preparación), acerca de la fabulosa canción "La guaria morada", su historia y autoría, que ofrecerá nuevos aportes y lecturas, porque estamos convencidos de que "flor" y "canción", como una alianza indivisible, están destinadas a permanecer en lo más profundo del alma costarricense. 


\section{Agradecimientos}

El autor agradece a:

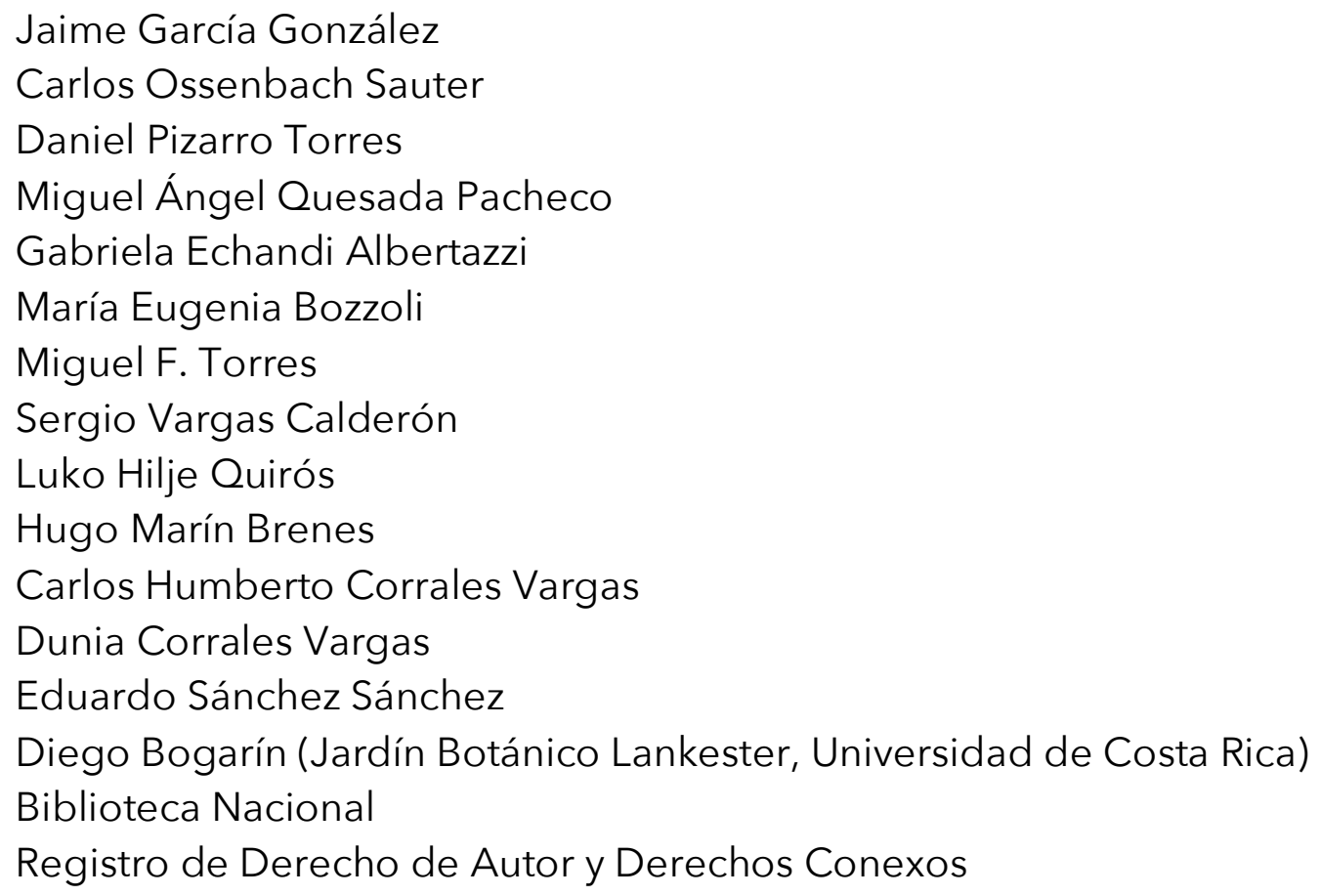

\section{BIBLIOGRAFÍA}

Alfaro, A. (1924). Las Orquídeas. Repertorio Americano, 7 abril de 1924, p. 40.

Agüero-Chaves, A. (1996). Diccionario de Costarriqueñismos.

Alvarado-Ulloa, C. (2000). Micropropagación de Cattleya skinneri y Cattleya skinneri x Cattleya maxima por cultivo de ápices. Informe de Proyecto de Graduación para optar por el grado de Bachiller en Ingeniería en Biotecnología. Instituto Tecnológico de Costa Rica.

Bateman, J. (1837-1843). The Orchidaceae of Mexico and Guatemala. London: Ridgway.

Colquhoun, K. (2006). The Busiest Man in England: A Life of Joseph Paxton, Gardener, Architect, and Visionary. Boston. David R. Godine.

Corrales-Vargas, U. (1979). Una tradición alajuelense. Texto inédito. 
Coutiño-Cortés et al. (2018). El uso ornamental de Guarianthe skinneri (Orchidaceae), en Chiapas y Guatemala, determina parcialmente su diversidad y estructura genética. Act. Bot. Mex [online]. n.124.

ISSN 2448-7589. Disponible en: http://dx.doi.org/10.21829/abm124.2018.1303

Chadwick (2015). The Myth Maker. Recuperado de: https://chadwickorchids.com/content/myth-maker

De Goeyen, J. (2000). Atardecer de un fauno. La Nación. Opinión. 22 agosto.

Dobles-Segreda, L. (1945). La Guaria Morada. Revista del Instituto de Defensa del Café de Costa Rica, junio.

Dowell, R. (1947). Coleccionando orquídeas en Costa Rica. Revista del Instituto de Defensa del Café de Costa Rica. No. 127. Junio. Tomo XV.

Dressler, R. (2003). Guarianthe, a generic name for the "Cattleya" skinneri complex. Lankesteriana. Vol 7: 37-38.

Gagini, C. (1919). Diccionario de Costarriqueñismos.

La Nación. (22 de agosto de 2000).

La Nación (5 de diciembre de 1984), p. $15^{a}$.

Martínez, F. (2003). La Guaria cambió de nombre. La Nacion, 23 de mayo, VIVA.

Milligan, B. (2003). George Skinner and His Orchids. Recuperado de:

https://www.oscov.asn.au/articles/george-skinner-and-his-orchids-by-brian-

milligan/

Ossenbach, C. (2004). La Guaria Morada en el siglo XIX. Texto para conferencia, con motivo de la celebración del 65 Aniversario de la declaratoria de la Guaria Morada como Flor Nacional de Costa Rica, Sede de la Universidad Nacional Estatal a Distancia. Texto inédito.

Ossenbach, C. (2016). Orquídeas y orquideología en América Central, 500 años de historia. Cartago: Editorial Tecnológica. 
Pittier, H. (1908). Ensayo sobre las Plantas Usuales de Costa Rica. Washington, p. 99.

Rivera-Coto, G. (1998). Orquídeas, generalidades y cultivo. Heredia: Editorial Fundación UNA.

Rigby, R. (2005). Highlights of Orchid History. Recuperado de: https://web.archive.org/web/20081012005836/http://www.rrigby.demon.co.uk/USAOHP1.pdf

Sancho-Jiménez M. (1961). Memorias. San José. Editorial Costa Rica.

Siegel, C. (2013). Bateman, Skinner, and the Kiddies. Recuperado de: http://glvos.org/Newsletters/Newsletter/2013/siegel3-8.pdf

The Gardeners' Chronicle. A Monster Cattleya Skinneri. Londres. Vol. XXI, enerojunio de 1884, p. 548.

Torres, M. F. (2019). "Etnobotánica Religiosa de Guatemala". Conferencia Episcopal de Guatemala. En prensa.

Uytoerhoeven, S (2013). Crazy for Cattleyas. New York Botanical Garden. Recuperado de:

https://www.nybg.org/blogs/plant-talk/2013/01/gardens-and-

collections/crazy-for-cattleyas/ 


\title{
ALBUM FOTOGRÁFICO
}

\author{
RENDIDOS ANTE LA GUARIA MORADA
}

Fotografía 1. Macolla de guarias, en el jardín de los hermanos Camacho García. Bo. Nuevo, Tejar de El Guarco, Cartago.

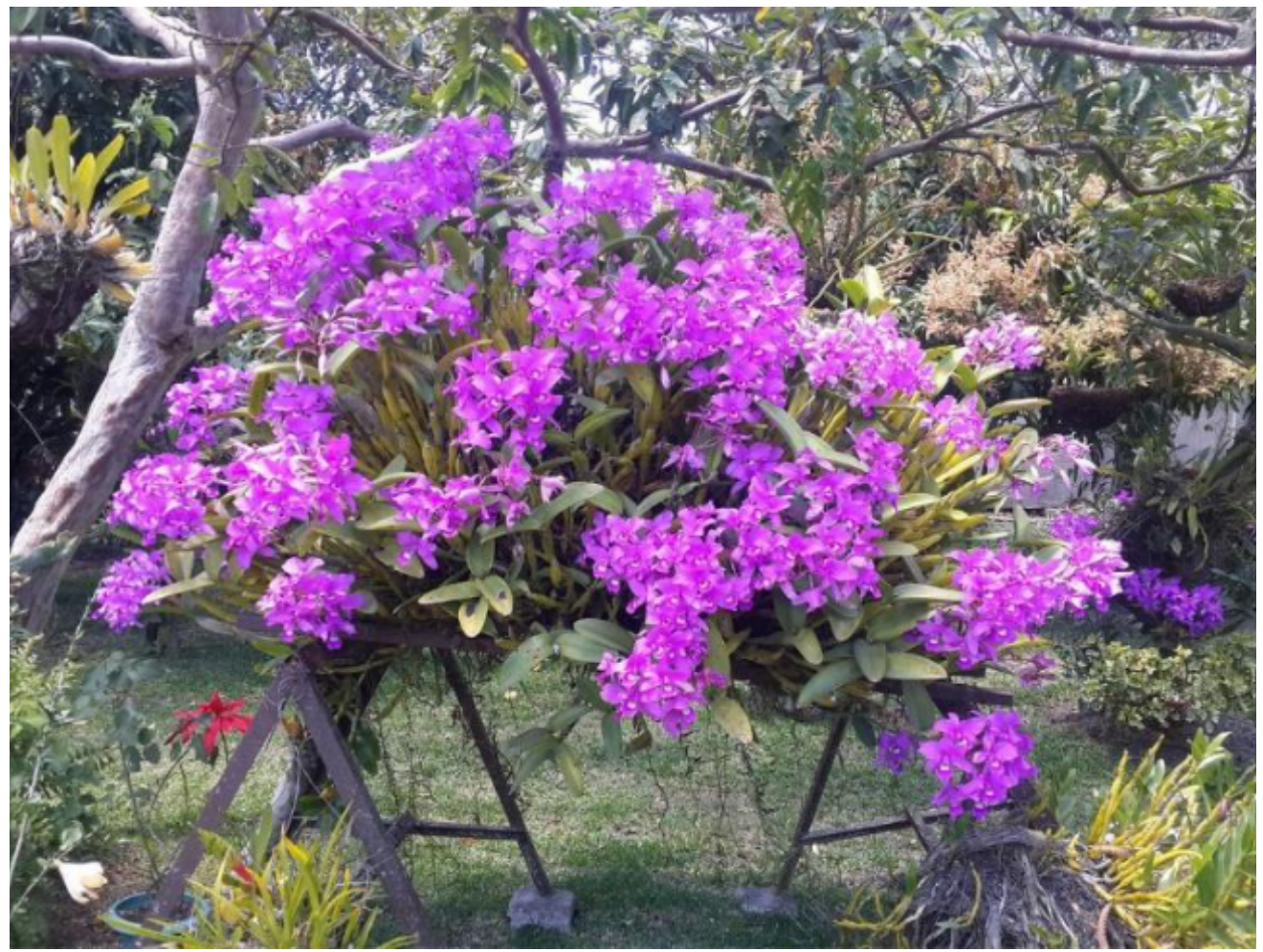

Foto: Sergio Orozco Abarca, 2019.

Fotografía 2. Billete de 5 colones, serie D, del Banco Central de Costa Rica, emitido desde 1968 hasta 1992 y, decorado con la guaria morada.

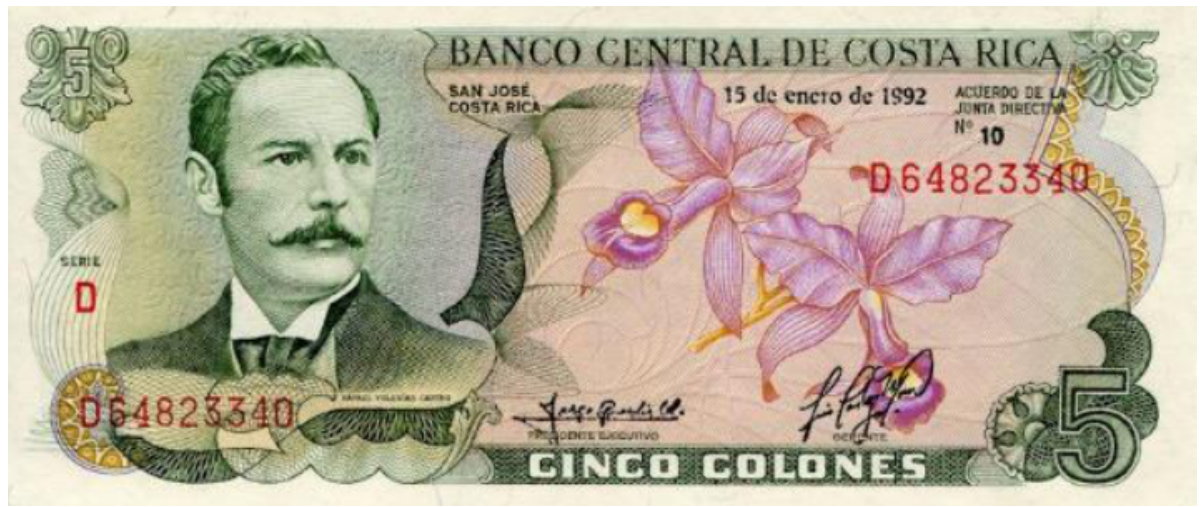

Fuente: Ilustración del Dr. Rafael Lucas Rodríguez Caballero. 
Fotografía 3. Estampilla con guaria morada, 1937. Es la primera estampilla del mundo donde aparece una orquídea

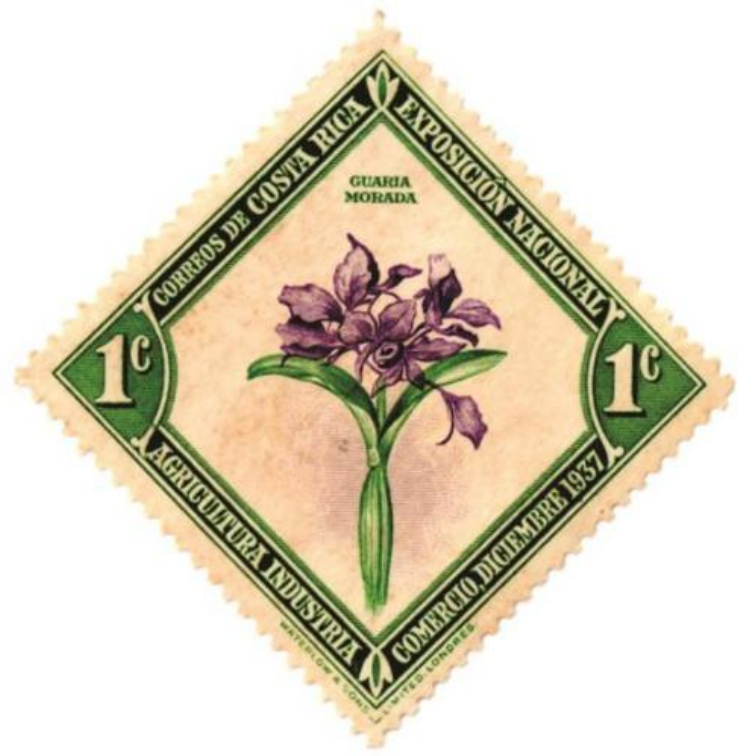

Autor: Evelyn Garrido Mora

Emisión: Exposición Nacional

Nombre de la Emisión: Exposición Nacional Agricultura, Industria y Comercio

Fecha de circulación: 1937

Valor facial: 1 colón

Fotografía 4. Estampilla con guaria morada, 1989.

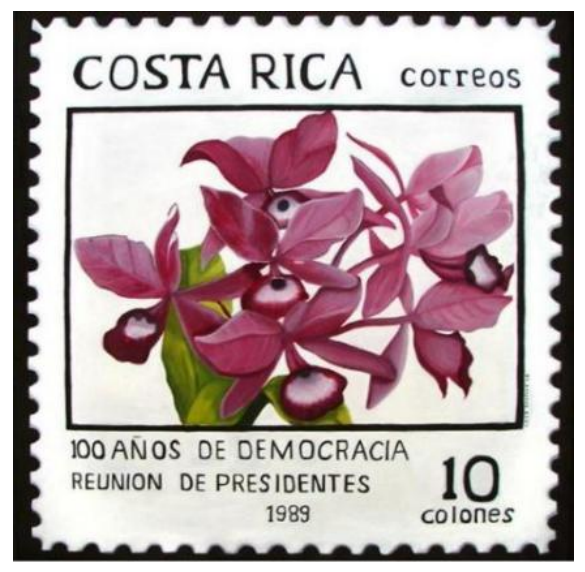

Estampilla con guaria morada. Autor: Laura Marchena Gómez Emisión: 100 años de Democracia

Nombre de la Emisión:100 años de Democracia Reunión de Presidentes Fecha de circulación: 1989

Valor facial: 10 colones 
Fotografía 5. Moneda conmemorativa del 25 aniversario del Banco Central de Costa Rica, con guaria morada. Imagen tomada de: "Monedas conmemorativas de Costa Rica 1847, 1970-2000, Leonardo Montalbán Roldán".

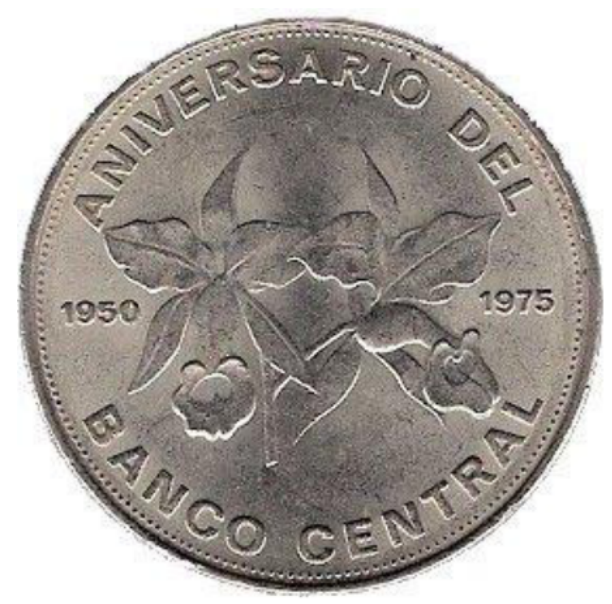

Fuente: recuperada de: https://issuu.com/atitec/docs/completo_conmemorativas_de_costa_ri

Fotografía 6. Fracción de lotería de la Junta de Protección Social de San José, con guaria morada. Sorteo del domingo 12 de marzo de 2000.

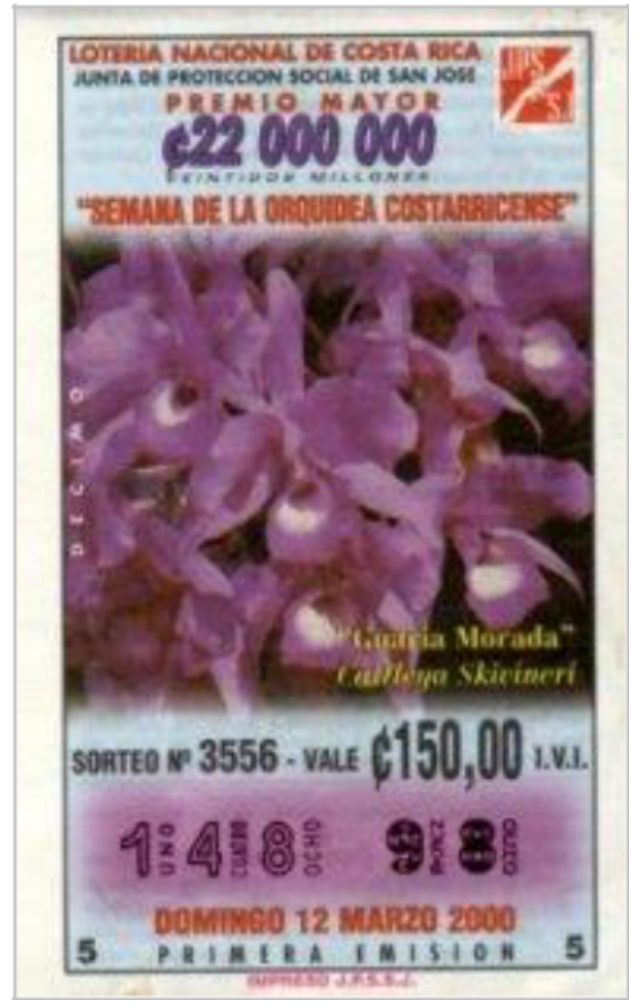

Imagen recuperada de: https://guiascostarica.info/simbolos/guaria morada/ 
Fotografía 7. Niña junto a una macolla de guarias.

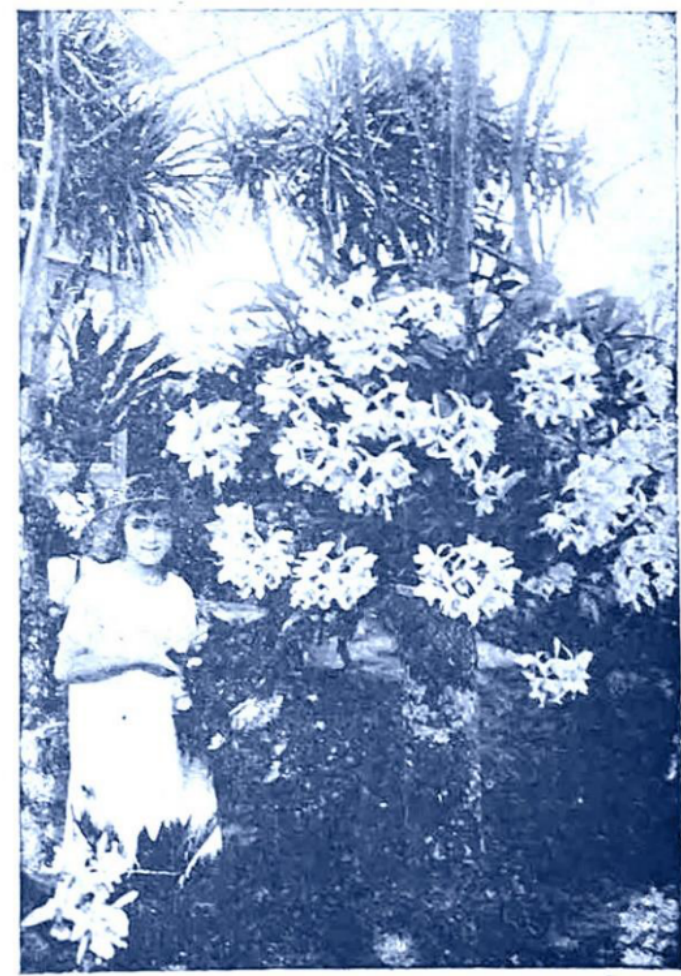

Fuente: libro "República de Costa Rica", Garnier, Editorial Gutemberg (1935).

Fotografía 8. Foto de George Ure Skinner.

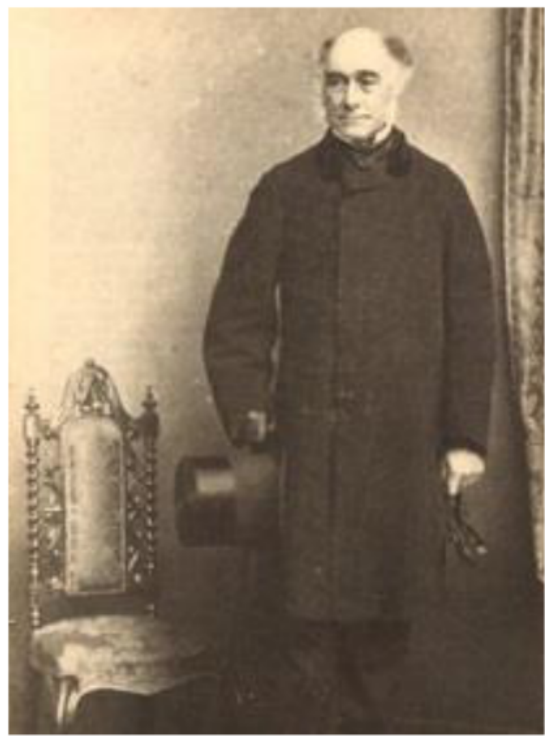

Fuente: Tomada de: http://orgulloguatemalteco.blogspot.com/2013/08/la-monja-blanca-flor-nacionalde.html 
Fotografía 9. Pintura del árbol de guarias (detalle) hecha por Julio Solera, en 1952.

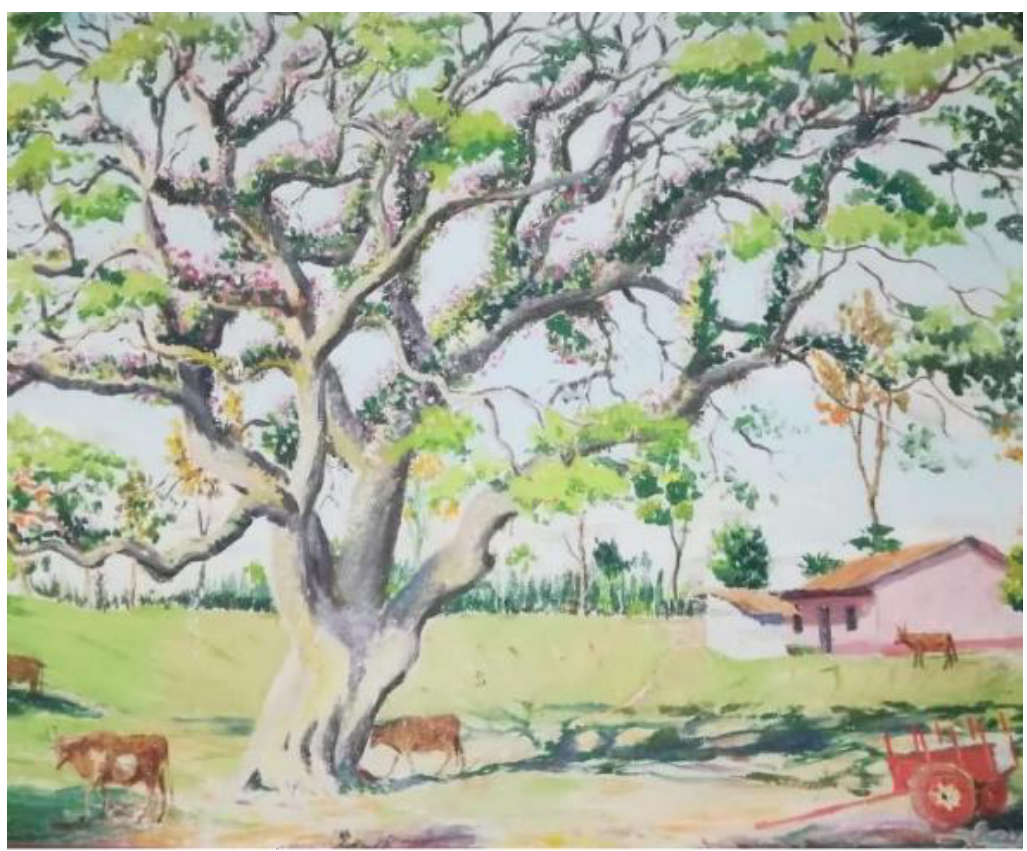

Fuente: Cortesía de doña Dunia Corrales Vargas.

Fotografía 10. Pintura del árbol de guarias hecha por el prof. Raúl Chaves de la Universidad Técnica Nacional, Alajuela. Sin fecha

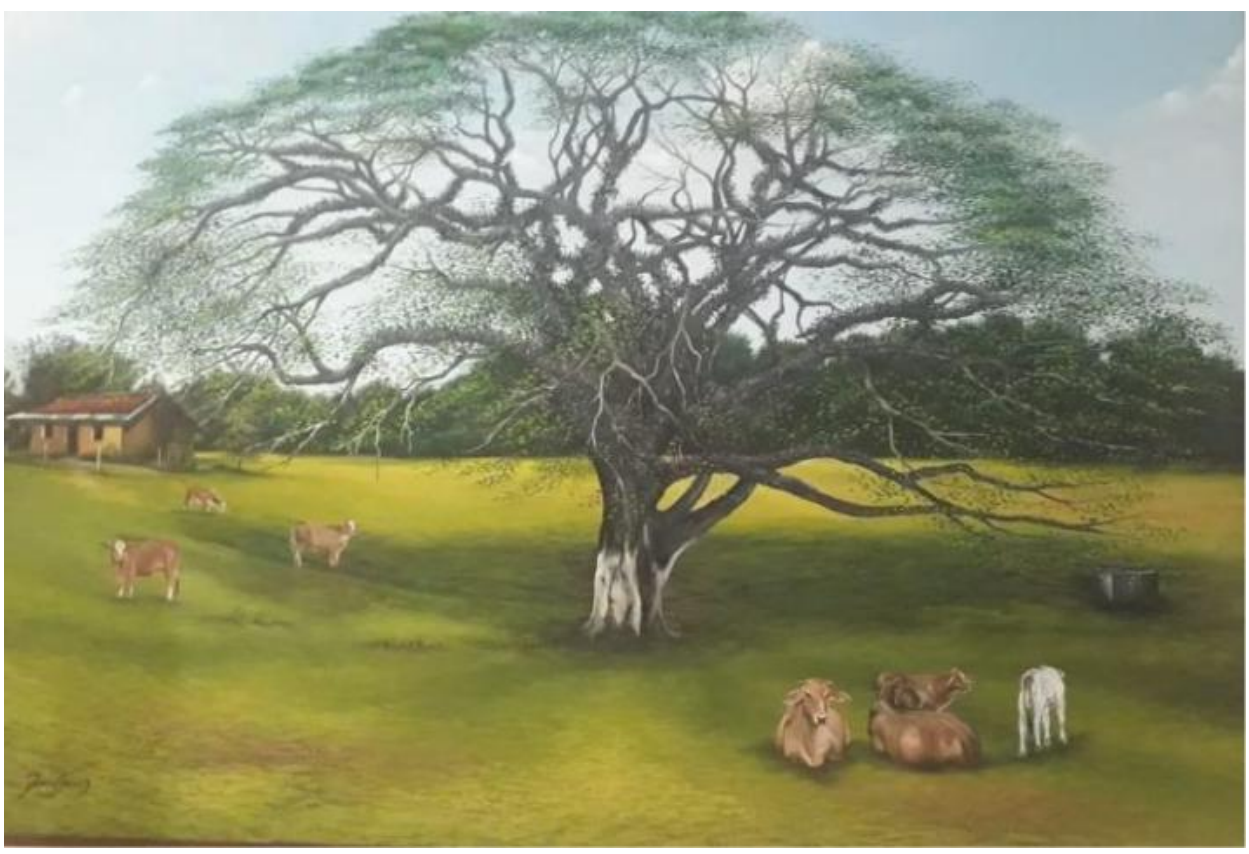

Fuente: Cortesía de doña Dunia Corrales Vargas. 
Revista Herencia, Vol. 33 (1), enero-junio, 2020.

Fotografía 11. Don Carlos Lankester (izquierda) con guaria de Turrialba.

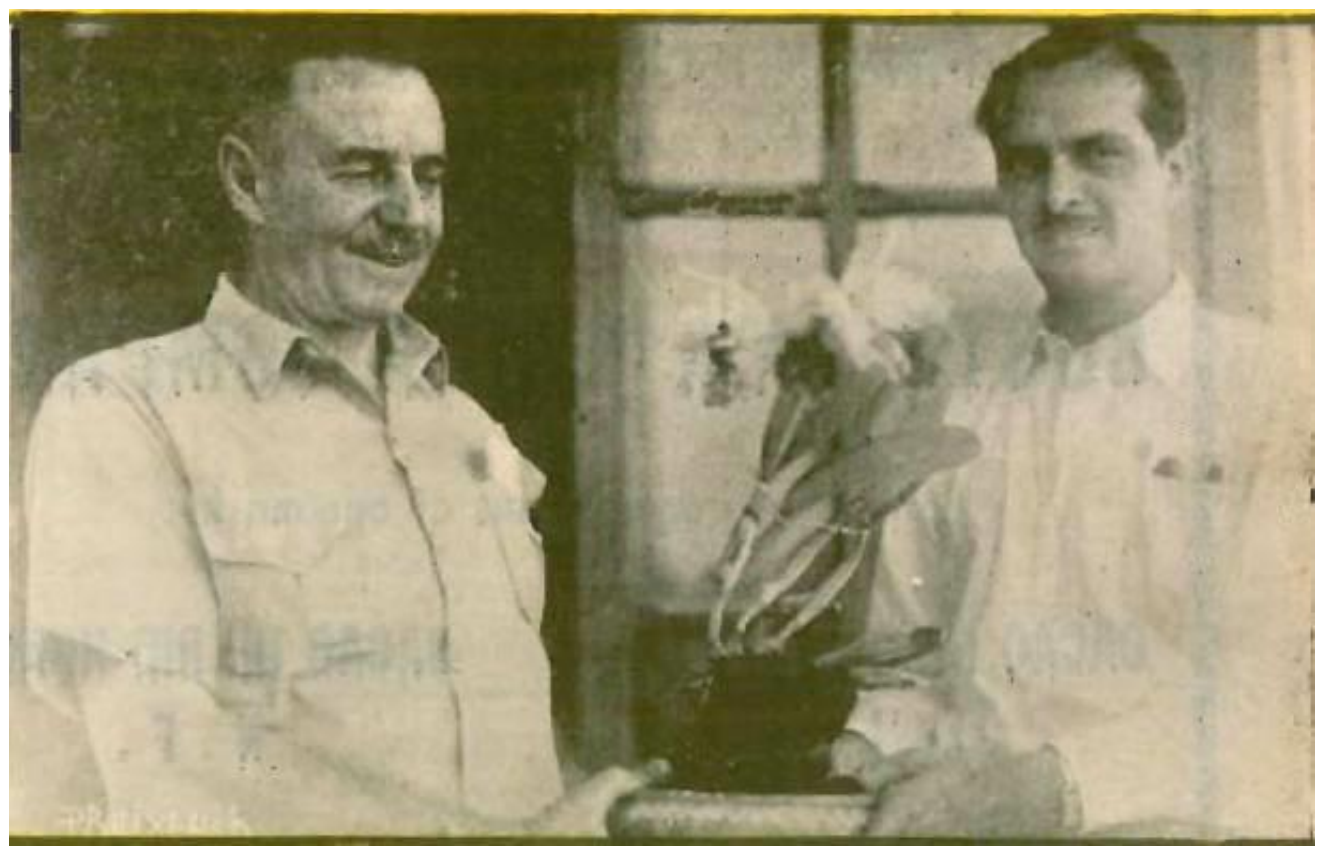

Fuente: sin datos.

Fotografía 12. Viveros "La Mil Flor" de Mr. Clausen, actual Bo. Luján, San José. 1915.

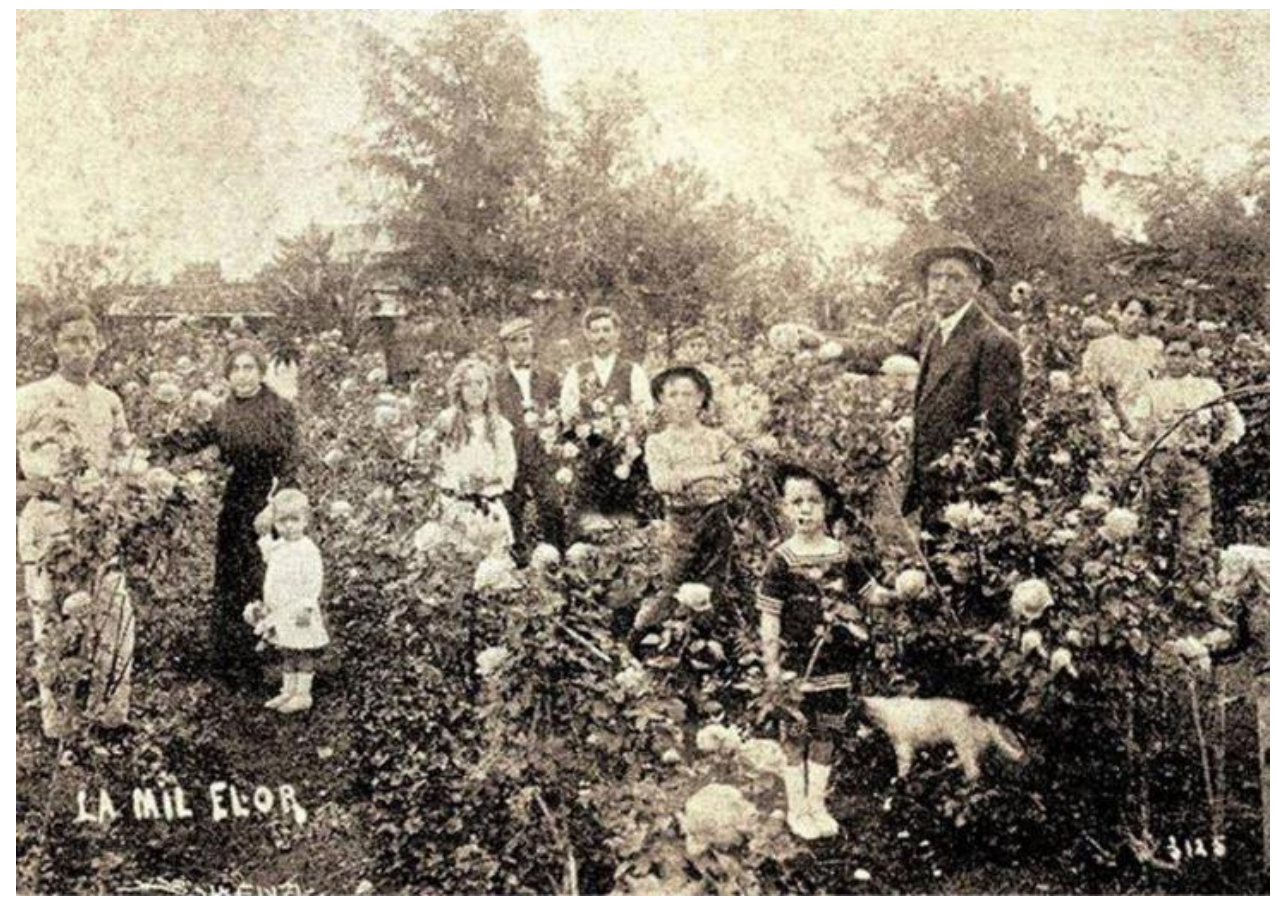

Fuente: tomada de fotos antiguas de Costa Rica (Facebook). 
Fotografía 13. Coronación de las princesas de la virgen de la Candelaria, en Cintalapa, Chiapas, año 2018.

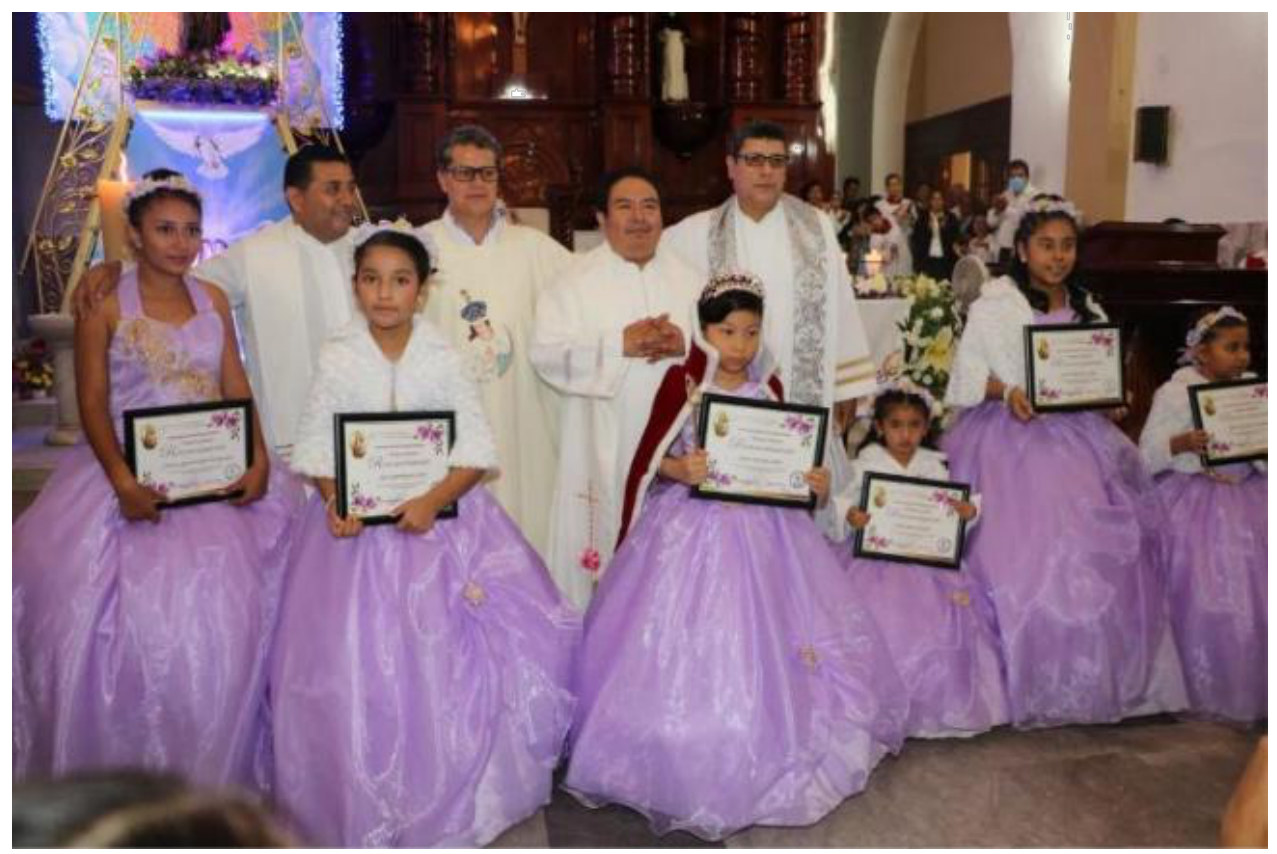

Fuente: Tomada de www.cintalapanecos.com

Fotografía 14. Programa de festividades en honor a la Virgen de la Candelaria, en Cintalapa, Chiapas, año 2018.

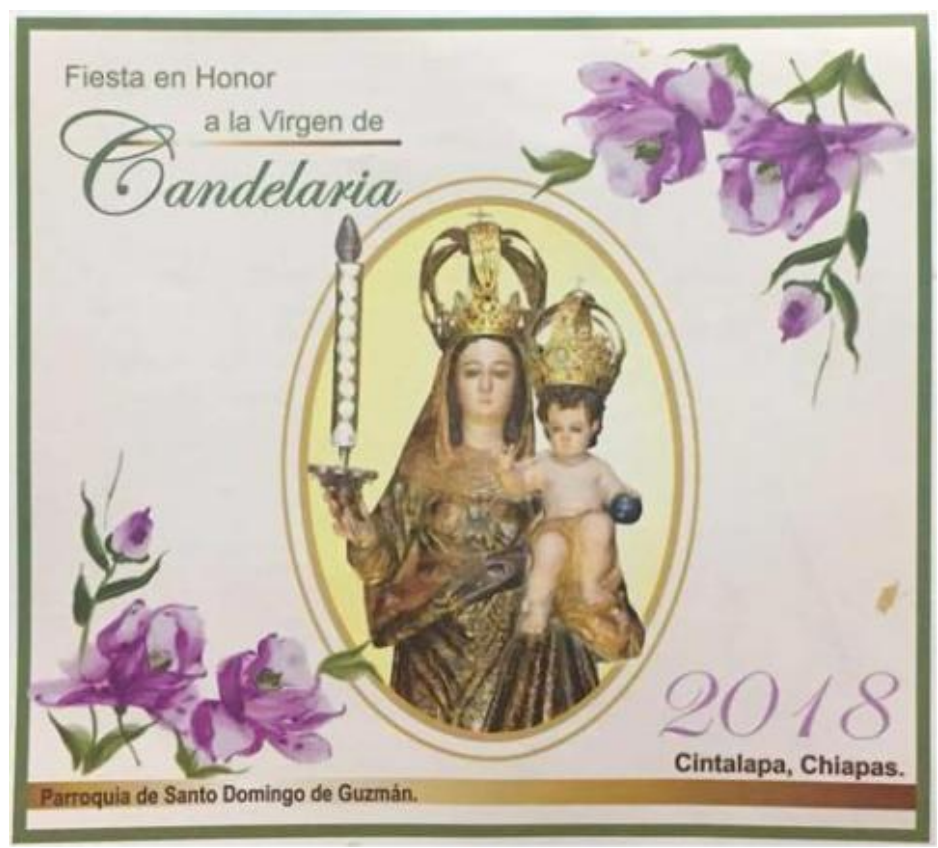

Fuente: Tomada de la página de Fecebook "Real Cintalapa". 
Fotografía 15. Coronación y mañanitas a la Virgen de la Candelaria, Cintalapa, Chiapas, año 2018.

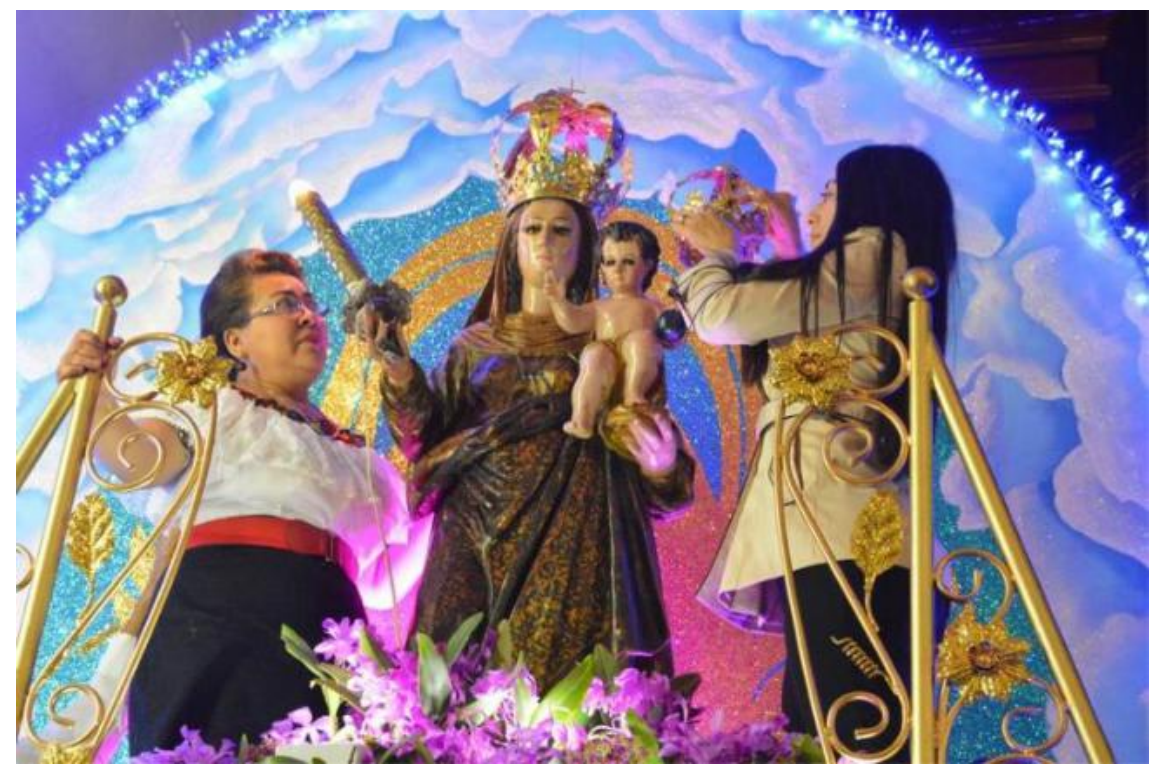

Fuente: Tomada de: www.cintalapanecos.com

Fotografía 16. Sir Joseph Paxton. Retrato de Maull \& Polyblank, Londres. Sin fecha. Probable de la década de 1850.

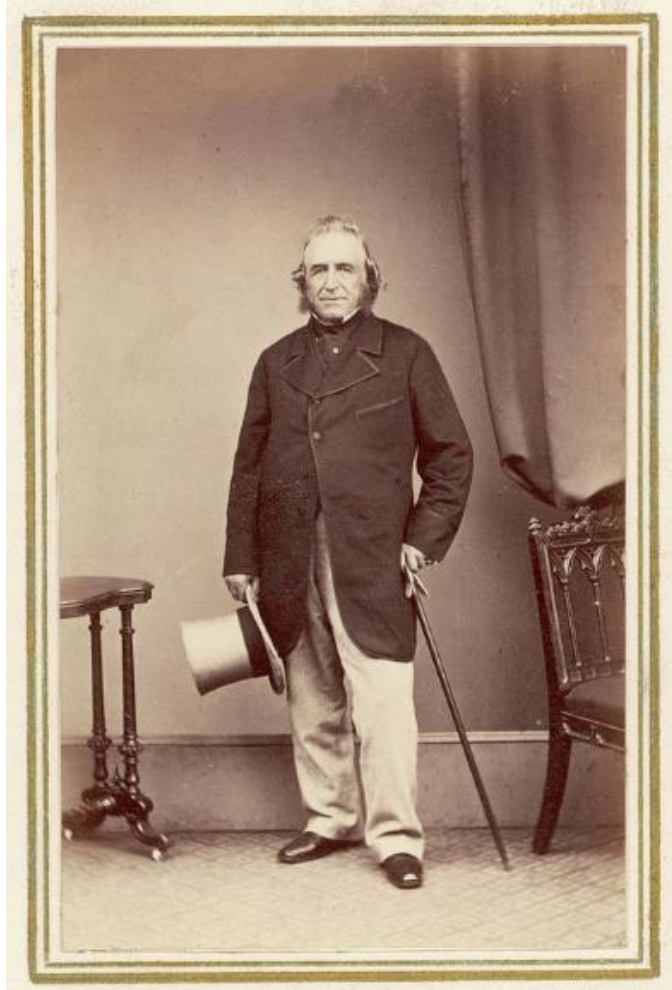

Fuente: sin datos. 
Revista Herencia, Vol. 33 (1), enero-junio, 2020.

Fotografía 17. El gran invernadero (Gran Estufa) de Chattsworth.

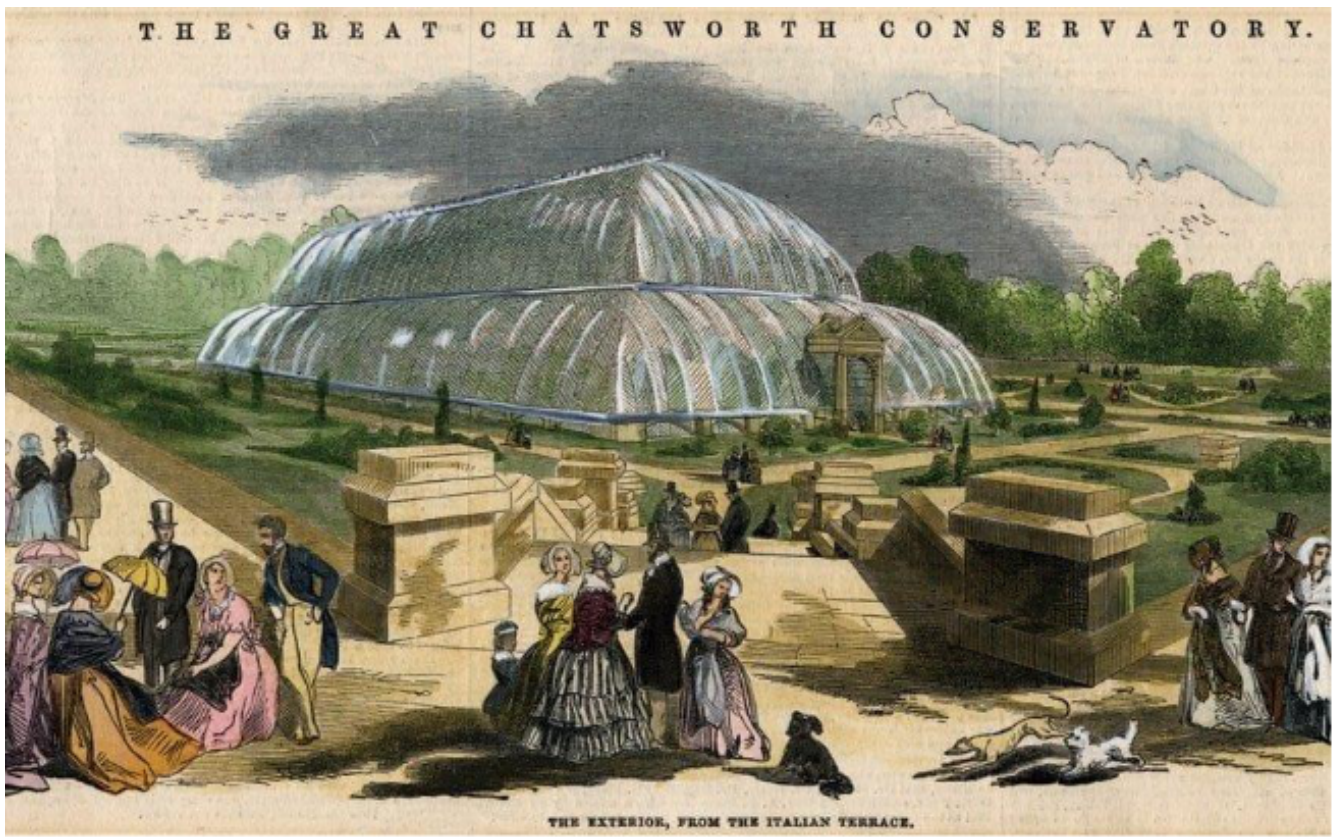

Fuente: Imagen de The Telegraph (Londres): www.telegraph.co.uk

Fotografía 18. Sir William Cattley.

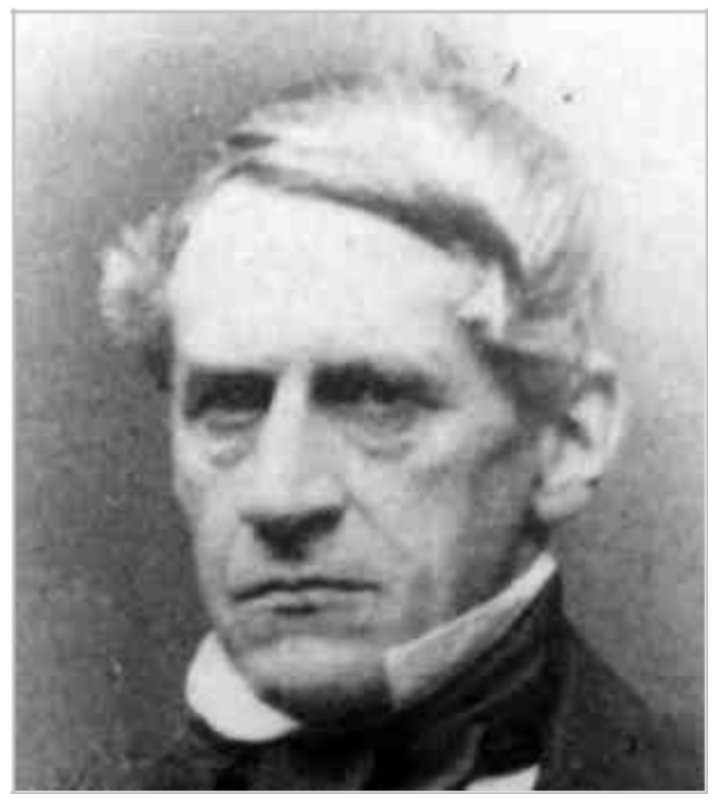

Fuente: Wikicommons. 
Fotografía 19. James Bateman (1811-1897).

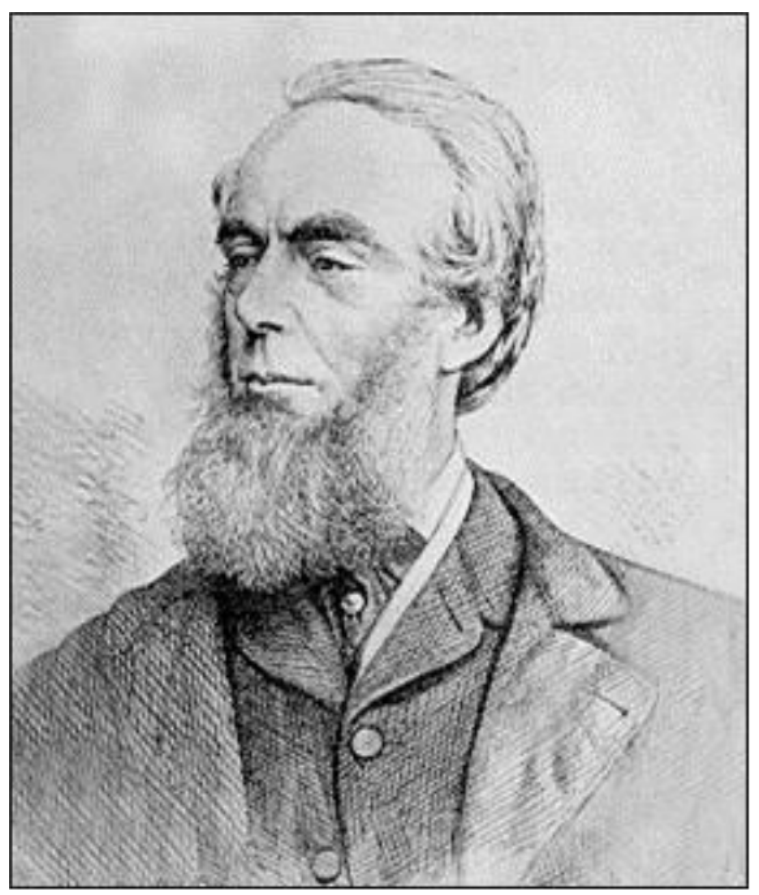

Fuente: Wikicommons.

Fotografía 20. John Lindley (1799-1865).

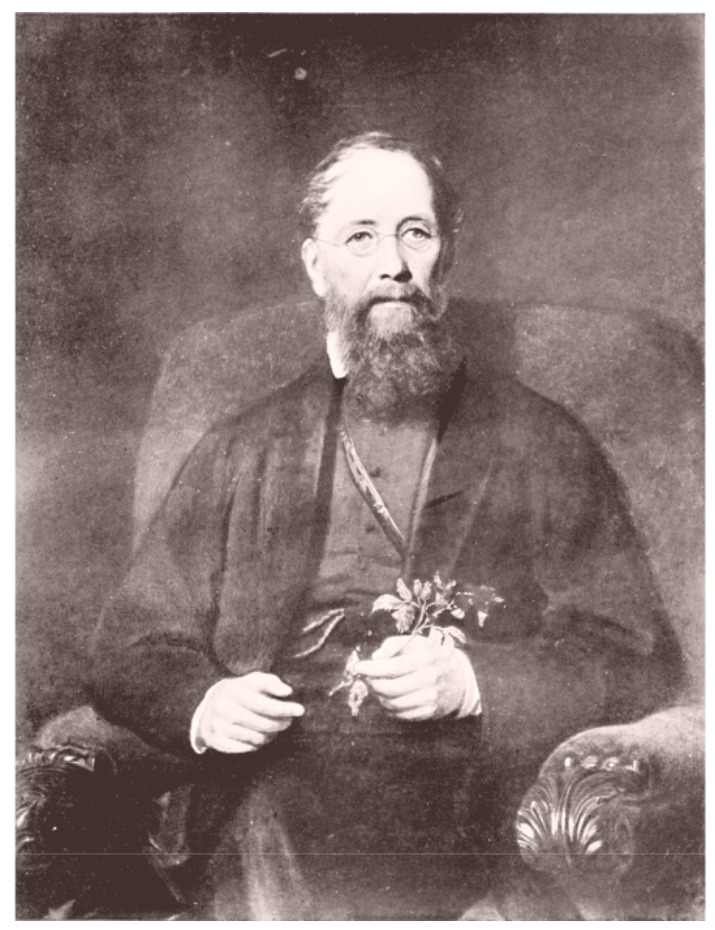

Fuente: Imagen Wikicommons. 
Fotografía 21. Un invaluable tesoro. Parte del archivo de G. U. Skinner, en venta en Ebay (al 4 de septiembre de 2019). Vendedor Planet-Auctions, de Portugal.

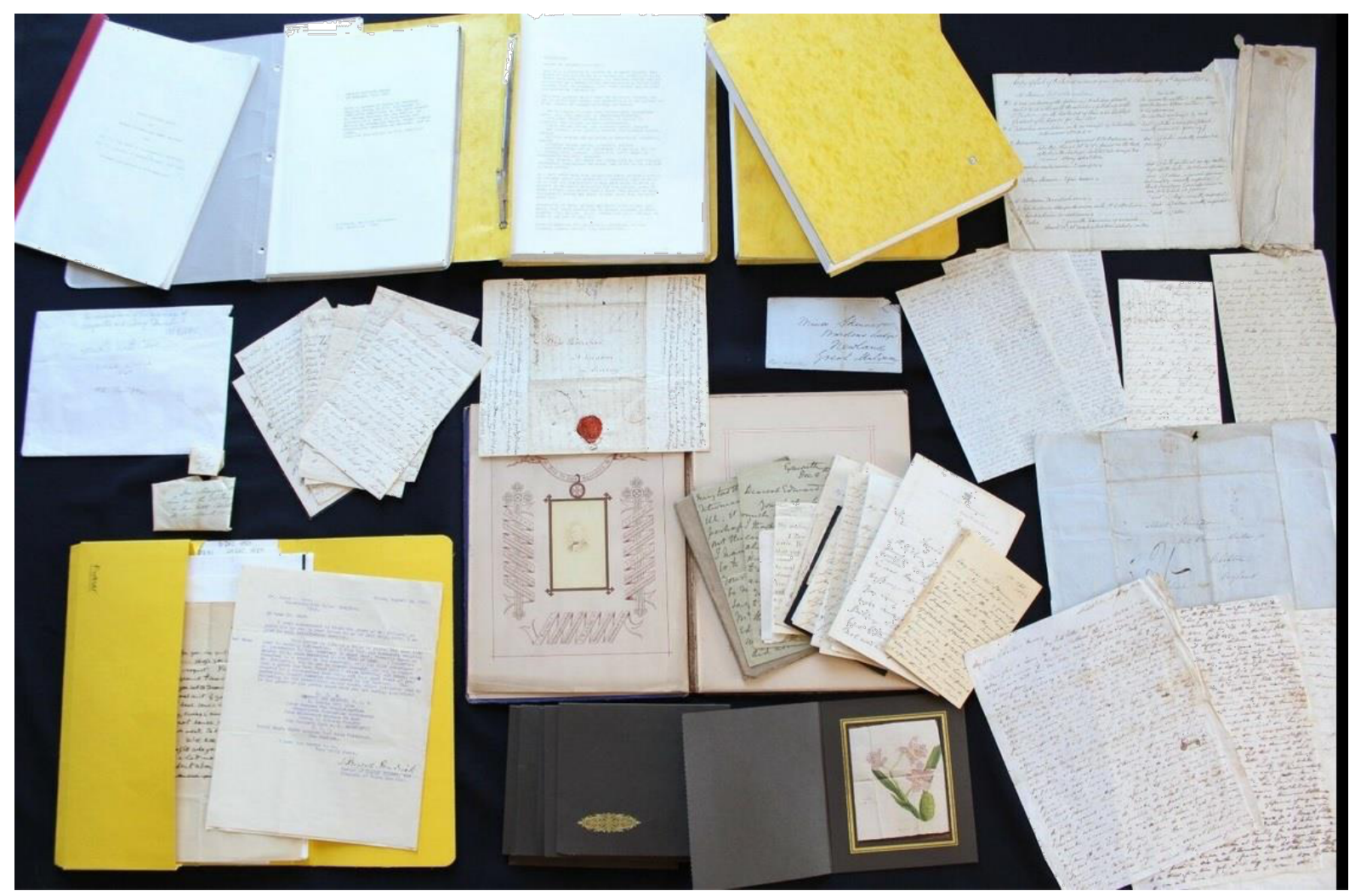

Fuente: Recuperada de: https://www.ebay.com/itm/Orchids-Skinner-Guatemala-Scottish-EpiscopalChurch-Important-Family-Archive-/113425121594 